\title{
Yläkoulun S2-oppilaiden transitiivi-ilmausten käyttö Eurooppalaisen viitekehyksen taitotasoilla
}

\author{
NINA REIMAN \\ Jyväskylän yliopisto
}

Tiivistelmä. Artikkelissa tarkastelen, miten transitiivi-ilmausten käyttö kehittyy yläkouluikäisten suomi toisena kielenä -oppilaiden Eurooppalaisen viitekehyksen (2003) taitotasoille arvioiduissa kirjoitelmissa. Tutkimuksen tavoitteena on selvittää, miten nuoret kirjoittajat käyttävät yleistä ja monikäyttöistä ilmaustyyppiä, transitiivikonstruktiota, oppijansuomessa ja miten konstruktion toteutumat muuttuvat ja varioivat kielitaidon kehittyessä. Tutkimusaineisto koostuu Jyväskylän yliopiston Cefling-hankkeessa 7.-9.-luokkalaisilta S2-oppilailta kerätyistä kirjoitelmista, joita analysoin transitiivi-ilmausten taajuuden ja tarkkuuden kannalta. Laadullisen tarkastelun lähtökohtana on käyttöpohjainen konstruktiokielioppi ja erityisesti se, millaisissa argumenttiympäristöissä oppijat transitiivi-ilmauksia käyttävät. Tulosten mukaan transitiivikonstruktiota käytetään kirjoitelmissa melko tasaisesti eri taitotasoilla. Toteutumien määrä kuitenkin vaihtelee tehtävittäin: epämuodollisissa viesteissä ilmauksia on vähiten, mielipiteissä ja muodollisissa viesteissä taas selvästi enemmän. Ilmaukset tarkentuvat tasaisesti taitotasolta toiselle, ja 80 \%:n tarkkuus saavutetaan B1-tasolla. A1-tasolla ilmaukset ovat argumenttirakenteeltaan usein vielä melko yksinkertaisia, mutta etenkin asettamis-, siirtämis-, antamis- ja ottamiskonstruktioita oppijat pyrkivät jo käyttämään. A2-tasolta eteenpäin argumenttirakennekonstruktioiden 
toteutumat lisääntyvät ja käytöt alkavat monipuolistua ja täsmentyä. Transitiivikonstruktion käyttö laajenee prototyyppisistä tapauksista etäämmälle.

Avainsanat: toisen kielen omaksuminen; oppijankieli; lauseoppi; transitiivisuus; konstruktiokielioppi; suomi

\section{Johdanto}

Toisen kielen osa-alueista kirjoittamista pidetään usein niin sanotun muodollisen kielitaidon ytimenä. Kirjoittaminen kuitenkin koetaan heikoimmaksi ja vaikeimmin hallittavaksi taidoksi, ja siinä on tyypillisesti myös eniten vaihtelua yksilöiden välillä (ks. Tarnanen \& Mäntylä 2006; 6.-luokkalaisten kirjoittamisesta Halonen 2007). Koulussa kirjoittaminen on lisäksi tärkeä osa opiskelutaitoja, ja siten se vaikuttaa myös yleiseen opinnoissa menestymiseen (Kuusela ym. 2008). Jos oppilaiden muodolliset kirjoittamistaidot ovat kovin heikot, ne voivat aiheuttaa haasteita myös tulevalle koulutustielle (Halonen 2007; Reiman \& Mustonen 2010). Kuten Reiman ja Mustonen (2010: 151) toteavat, “[k]oulukontekstissa kirjoittamistaito on paitsi tekstilajikonventioiden ja niihin liittyvien kieliopillisten rakenteiden ja sanaston hallintaa, myös sisältöjen, kielen ja ajattelun jäsentämisen keino".

Kirjoittamistaidon kannalta kielen rakenteista erityisen keskeisinä voidaan pitää lauserakenteita. Koska tilannekonteksti vaikuttaa kielenkäyttöön ja sen variaatioon (Halliday 2003: 437), lauserakenteiden monipuolinen osaaminen on edellytys muun muassa tekstilajin mukaiselle kirjoittamiselle. Eri tekstilajeissa tietyt rakenteet ovat tyypillisempiä kuin toiset (ks. Mäntynen 2006: 42): esimerkiksi mielipideteksteissä tavallisia ovat erilaiset geneeriset ilmaustyypit (Seilonen 2013: 160). Oppijoilla laaja syntaktisten keinojen valikoima toimii siis kirjoittamisen resurssina, joka mahdollistaa tilanteen- ja tehtävänmukaisen kielenkäytön. Vastaavasti taas lauserakenteiden yksipuolisuus saattaa kaventaa ilmaisun täsmällisyyttä ja ongelmat puolestaan voivat vaikuttaa tekstin luettavuuteen ja ymmärrettävyyteen. 
Lauserakenteen ilmiöt ovat herättäneet viime vuosina yhä enenevässä määrin kiinnostusta myös suomi toisena kielenä (S2) -tutkimuksessa. Seilonen (2013) on tarkastellut epäsuoran henkilöön viittaamisen keinoja ja Kajander (2013) eksistentiaalilauseen kehittymistä oppijansuomessa. Ivaska (2011; Ivaska \& Siitonen 2011) puolestaan on selvittänyt edistyneiden oppijoiden lauserakennetta korpusvetoisesti ja Seppälä (2013) suomi vieraana kielenä -oppijoiden ketjuuntuvia verbirakenteita. Morfosyntaktisia ilmiöitä ovat valottaneet muun muassa Siivelt ja Mustonen (2013) paikallissijojen sekä Spoelman (2012) partitiivin käytön osalta. Tämä artikkeli keskittyy transitiivi-ilmausten tarkasteluun yläkoululaisten nuorten kirjoitetussa oppijansuomessa. Tutkimuksen tavoitteena on selvittää, miten transitiivikonstruktion käyttö kehittyy ja muuttuu kirjoitelmissa, jotka edustavat Eurooppalaisen viitekehyksen (EVK 2003; tästä eteenpäin myös EVK tai viitekehys) eri taitotasoja. Transiitivikonstruktio on suomen kielessä yleinen ja monikäyttöinen ilmaustyyppi, joka toteutuu kielenkäytössä erilaisina transitiivi-ilmauksina. Lähemmin keskityn seuraaviin tutkimuskysymyksiin:

- Miten transitiivi-ilmausten taajuus ja tarkkuus kehittyvät taitotasoittain?

- Millaisia laadullisia muutoksia transitiivi-ilmauksissa tapahtuu tasolta toiselle?

- Miten transitiivikonstruktion käyttö varioi ja monipuolistuu: millaisissa argumenttiympäristöissä konstruktiota käytetään?

Transitiivi-ilmausten käyttöä ja kehitystä tarkastelen käyttöpohjaisen konstruktiokieliopin näkökulmasta, jossa lauserakenteita lähestytään kielenkäytöstä kehkeytyvinä konstruktioina. Käyttöpohjainen lähestymistapa ohjaa kiinnittämään huomiota myös siihen, miten nuorten ilmauksissa näkyy kohdekielisen (oppimis)ympäristön vaikutus. 


\section{Tutkimuksen lähtökohdat}

\subsection{Käyttöpohjaisuus ja konstruktiokielioppi}

Tutkimuksen teoreettinen lähestymistapa on käyttöpohjainen (engl. usage-based) konstruktioajattelu (mm. Bybee 1985; 2006; 2008; Fillmore \& Kay 1995; Goldberg 1995; 2006; konstruktioajattelusta myös Kotilainen 2007: 19). Käyttöpohjaisen ajattelun mukaan kieltä opitaan vuorovaikutuksessa ja kielellinen tieto perustuu kielen käyttöön: Oppija hahmottaa ympäröivästä kielestä yhtäläisyyksiä ja eroja ja havaitsee säännönmukaisuuksia. Kielellisten keinojen valikoima alkaa muodostua analogioista ja yleistyksistä, jotka emergoituvat muistissa olevien analysoimattomien kokonaisuuksien (chunks, formulas) ja kielellisten kokemusten perusteella. (Esim. Langacker 1987; Ellis 2002: 318-322; 2003; Tomasello 1992; 2003: 144; Hopper 1987; 1998; Aslin \& Newport 2012.)

Konstruktioajattelun mukaan kielenkäytössä kohdatuista ilmauksista ja kokonaisina opituista kiteytymistä alkaa abstrahoitua kielen rakennetta koskevia yleistyksiä ja säännönmukaisuuksia, konstruktioita, sekä konstruktioiden välisiä yhteyksiä (Verhagen 2005: 24). Tähän prosessiin vaikuttaa etenkin tyyppifrekvenssi: mitä useammin oppija kohtaa erilaisia saman konstruktion toteuttavia ilmauksia, sitä todennäköisemmin näistä kokemuksista alkaa abstrahoitua yleistys, ilmauksen malli (esim. Bybee 2008). Konstruktio voidaan siis määritellä kielenpuhujien muodostamaksi kokemusperäiseksi ilmauksen malliksi, vakiintuneeksi muodon ja merkityksen yhteenliittymäksi (J. Leino 2003; 2010: 81). Oppimisprosessin edetessä yleistykset myös muokkautuvat ja konstruktioiden variaation rajat hahmottuvat: kielenkäyttäjä oppii esimerkiksi, millaiset leksikaaliset yksiköt konstruktioon sopivat sekä millaisten muiden konstruktioiden kanssa se voi yhdistyä (J. Leino 2010: 76, 81-83). (Ks. myös Reiman 2011.)

Kielenkäyttäjien repertoaariin kuuluu samanaikaisesti sekä hyvin abstrakteja syntaktisia konstruktioita - kuten transitiivikonstruktio että yksittäisiin sanoihin ja fraaseihin perustuvia konkreettisia ilmauksia (Tomasello 2003: 6; Ellis 2002; Bybee 2008: 218; 2010: 15). Kielellisen tiedon ajatellaan muodostavan toisiinsa liittyvien ja vuorovaikutuksessa 
toimivien konstruktioiden verkoston, ja uusia ilmauksia muodostetaan yhdistelemällä konstruktioita (Goldberg \& Suttle 2010: 468). Kehkeytyviä kielellisiä keinoja tarkastellaan osana kehittyvää konstruktioiden verkostoa. Kielellisten resurssien kasvaessa konstruktioiden verkosto laajenee ja tihentyy ja konstruktioiden rajat alkavat täsmentyä.

\subsection{Tutkimuskohde: transitiivikonstruktio ja sen variaatio erilaisissa argumenttiympäristöissä}

Suomen transitiivilausetta on selvitelty paljon etenkin objektin sijamuodon määräytymisen kannalta (mm. Larjavaara 1991; 1992; P. Leino 1991). Objekti on kiinnostanut myös toisen kielen oppimisen näkökulmasta (esim. Löflund 2001), sillä vielä edistyneetkin oppijat kokevat sijavalinnan vaikeaksi (esim. Göken 2012). Transitiivilauseiden yleisyyttä sekä sijamuodon valintaa ovat tarkastelleet pro gradu -töissään myös mm. Ånäs (2008), Salmi (2010) ja Kokkonen (2012). Tässä tutkimuksessa objektin sijavalinta ja tarkkuuden kehitys muodostavat lähinnä ilmiön muuta kehitystä taustoittavan näkökulman ja keskiössä on sen sijaan yleisen ja monikäyttöisen ilmausmallin, transitiivikonstruktion, muutos ja variaatio nuorten kirjoittajien oppijansuomessa.

Suomen kielen prototyyppinen transitiivikonstruktio on tyyppiä SVO tai täsmällisemmin konstituenttirakenteena $\mathrm{NP}_{\text {nom }}+\mathrm{V}+\mathrm{NP}_{\text {nom/ }}$ ${ }_{\text {gen/part }}{ }^{1}$ (P. Leino 2001: 28). Vaikka subjekti kuuluu transitiiviverbin ns. pakollisiin argumentteihin ${ }^{2}$, se voi suomessa jäädä ilmaisemattakin

1 Objektin sijamuodoista esim. ISK (2004: 881-883) käyttää nimityksiä totaaliobjekti (aiemmin akkusatiivi) ja partitiiviobjekti. Tässä olen merkinnyt sijamuodoiksi nominatiivin, genetiivin ja partitiivin, sillä oppijan on tiedettävä, kumpaan muotoon (nominatiiviin vai genetiiviin) totaaliobjekti kulloinkin tulee. Persoonapronominien akkusatiivimuoto on neljäs vaihtoehto, mutta olen jättänyt sen pois tästä prorotyyppisen konstruktion kuvauksesta.

2 Rakenteellisen transitiivisuuden kannalta merkityksellisenä piirteenä pidetään eksplisiittisesti ilmaistujen argumenttien määrää: vain lauseita, joissa on (vähintään) kaksi argumenttia, voidaan pitää transitiivisina. Muita keskeisiä piirteitä ovat argumenttien sijanmerkintä sekä verbin morfosyntaksi. (Ks. Kittilä 2002: 47.) 
esimerkiksi yksipersoonaisessa passiivissa tai nollapersoonaisissa lauseissa. Semanttisesti konstruktion prototyyppinen subjekti on rooliltaan tekijä eli agentti ja objekti tilan tai sijainnin muutoksen kokija eli patientti (ISK 2004: 866, 885). Prototyyppisen transitiivikonstruktion toteuttava lause olisi esimerkiksi Mikko kasteli kukat. Tutkimuksessani transitiivisuuden määritelmä on kuitenkin ennen muuta syntaktinen: tarkastelen transitiivisina ilmauksia, joissa on jonkinlainen tunnistettava objektiargumentti. Olen rajannut tutkimuskohteekseni tarkemmin ainoastaan nominiobjektin sisältävät transitiivi-ilmaukset, sillä S2-oppijoiden näkökulmasta suomen kielen erityispiirre on juuri sijavaihtelullinen objekti. Tällaisten transitiivi-ilmausten käyttö edellyttää syntaktisen objektin tunnistamista myös semanttisesti vähemmän transitiivisista ilmauksista (ks. Reiman 2011).

Kognitiivisesta näkökulmasta suomen kielen transitiivilausetta on tarkasteltu lähinnä fennistisessä tutkimuksessa (etenkin P. Leino ym. 2001). Pentti Leino (2001: 28) nojaa kognitiiviseen kielioppiin ja käyttää "keskeisestä ja usein toteutuvasta syntaktisesta rakennemallista" nimitystä TRANSITIIVI-skeema tai TRANSITIIVI-konstruktio. Hänen mukaansa "rakenne saattaa yhdistyä lukuisiin muihin rakenneskeemoihin ja muodostaa näin yhä mutkikkaampia rakenteita (ja niitä edustavia lausetyyppejä)" (P. Leino 2001: 29). Omassa tutkimuksessani olenkin kiinnostunut siitä, millä tavalla yläkoululaiset oppijat varioivat prototyyppistä transitiivikonstruktiota, millaisten muiden konstruktioiden kanssa se esiintyy kirjoitelmissa ja millaisina ilmauksina se toteutuu oppijoiden kielenkäytössä. Kansainvälisessä tutkimuksessa transitiivikonstruktion kehitystä ja oppimista on tutkittu ennen muuta ensikielen omaksumisen näkökulmasta (esim. Theakston ym. 2013; Graf ym. 2014).

Tässä artikkelissa transitiivikonstruktio on siis ennen kaikkea kielentutkijan työkalu sen tarkastelemiseen, millä tasoilla erilaiset transitiiviilmaukset näyttävät ilmaantuvan kielenoppijoiden resursseihin: millä tavoin prototyyppisen konstruktion käyttö alkaa laajentua ja eriytyä sekä konstruktioiden tai konstruktion varianttien verkosto kehittyä funktionaalisen kielitaidon edistyessä (ks. myös Reiman 2011). Tarkastelemani 
ilmaukset kytkeytyvät transitiivikonstruktioon nimenomaan jonkinlaisen tunnistettavan objektielementin kautta. Ilmaukset voivat olla ulompana prototyyppisen konstruktion keskiöstä tai limittyä osin muiden konstruktioiden kanssa. Tällaista prototyypistä etäällä olevaa transitiiviilmausta edustaa esimerkiksi lause Tämä pitää ottaa huomioon. Subjekti puuttuu kokonaan, ja sen tilalla teemapaikalla on objekti, joka on semanttiselta rooliltaan kohde. Objekti ei myöskään ole finiittiverbin, vaan $A$-infinitiivin argumentti. Lisäksi ilmaus toteuttaa samanaikaisesti sekä nesessiivi- että transitiivikonstruktion.

Hyödynnän joitakin olemassa olevia tulkintoja ja määrittelyjä tarkentaakseni kuvaa transitiivikonstruktion käytöstä, soveltamisesta ja mahdollisesta muutoksesta. Keskityn artikkelissa etenkin siihen, millaisessa argumenttiympäristössä transitiivikonstruktiota käytetään. Yhtenä tarkasteluani täsmentävänä välineenä käytän argumenttirakennekonstruktiota (Goldberg 1995; 2006). Jaakko Leinon (2010: 80) mukaan argumenttirakennekonstruktiot ovat "muodon ja merkityksen yhteenliittymiä, joilla on oma, leksikaalisesta aineksesta riippumaton merkityksensä’. Lähemmin avaan tätä analyysini työkalua luvussa 3 Aineisto ja menetelmät.

\section{Aineisto ja menetelmät}

Tutkimuksen aineisto on kerätty Cefling-hankkeessa ${ }^{3}$ ja käsittää yhteensä 447 kirjoitelmaa 7.-9.-luokkalaisilta S2-oppilailta. Tekstit on kirjoitettu neljästä erilaisesta viestinnällisestä tehtävästä, joita ovat viesti kaverille tai opettajalle, viesti verkkokauppaan, mielipide sekä tarina. Aineisto on arvioitu Eurooppalaisen viitekehyksen (EVK 2003) taitotasoille. Täsmälliset teksti- ja sanemäärät taitotasoittain näkyvät taulukossa 1. Yläkoululaisten kirjoitelmat eivät yllä B2-tasoa korkeammalle, ja tämäntasoisia suorituksiakin aineistossa on vain 29 .

3 Cefling - Linguistic Basis of the Common European Framework for L2 English and L2 Finnish, project pages https://www.jyu.fi/hum/laitokset/kielet/tutkimus/hankkeet/paattyneet-hankkeet/cefling/en (21.2.2014). 
Taulukкo 1. Aineiston teksti- ja sanemäärät

\begin{tabular}{|l|c|c|c|}
\hline Kielitaitotaso & Sanemäärä & Tekstien määrä & $\begin{array}{c}\text { Sanemäärien } \\
\text { keskiarvo }\end{array}$ \\
\hline A1 & 3479 & 115 & 30,3 \\
\hline A2 & 9044 & 199 & 45,4 \\
\hline B1 & 11317 & 184 & 61,5 \\
\hline B2 & 2223 & 29 & 76,7 \\
\hline
\end{tabular}

Tekstit on litteroitu ja koodattu CHILDES-järjestelmän ${ }^{4}$ CHAT-koodaus- ja transkriptiojärjestelmällä (ks. MacWhinney 2000). Transitiivi-ilmausten alustavan koodauksen perusteena on ollut objektin esiintyminen ilmauksessa (ks. transitiivisuuden määrittelystä luku 2.2). Koodatut CHAT-tiedostot olen analysoinut CLAN-ohjelmalla ${ }^{5}$.

Artikkelissa tarkastelen määrällisesti, kuinka transitiivi-ilmausten käyttö lisääntyy (taajuus/frekvenssi) ja niiden oikeellisuus kehittyy (tarkkuus). Taajuuden olen laskenut tarkasteltavan ilmauksen esiintymiskerroista 1000:ta tekstisanaa eli sanetta kohden. Tätä laskentatapaa voi pitää jossain määrin ongelmallisena, sillä menetelmä häivyttää sen muutoksen, että kielitaidon kehittyessä myös lauseet yleensä pitenevät. Yleensä lausetason ilmiöitä suhteutetaankin tekstin lauseiden määrään. Varsinkin oppijankielen kehityksen alkuvaiheissa (A-tasolla) lauserajojen yksiselitteinen määrittely ja siten lauseiden määrän luotettava laskeminen on kuitenkin osoittautunut hankalaksi: teksteissä voi olla esimerkiksi kokonaan predikaatittomia ilmauksia tai vastaavasti ilmauksia, joissa on useita predikaatiksi tulkittavia verbejä. Myös välimerkkejä saatetaan käyttää hyvin sattumanvaraisesti. (Ks. Martin 2013; Kajander 2013: 87; Seilonen 2013: 31.)

Transitiivi-ilmausten tarkkuutta voisi tarkastella monen eri kielen piirteen osalta. Koska suomen kielen transitiivikonstruktiolle ominainen - ja toisaalta oppijoiden hankalaksi kokema - piirre on kuitenkin

$4 \quad$ CHILDES $=$ The Child Language Data Exchange System, ks. childes.psy.cmu.edu. $5 \quad$ CLAN = Computerized Language Analysis, ks. http://childes.psy.cmu.edu/ manuals/CLAN.pdf. 
objektin sijamuodon vaihtelu, on kohdekielen mukaisuuden kriteeriksi valittu tässäkin tutkimuksessa objektin sijavalinta. Kohdekielisiksi on näin ollen laskettu sellaiset transitiivikonstruktion toteutumat, joissa sijavalinta on norminmukainen.

Aineistoni laadullinen tarkastelu perustuu käyttöpohjaisen konstruktiokieliopin ajatukseen, jossa kielellisten resurssien kasvaminen nähdään konstruktioiden verkoston laajenemisena ja tihentymisenä. Koska konstruktiot ovat muodon ja merkityksen yhteenliittymiä, kielitaidon kehittyessä ja konstruktioiden eriytyessä myös ilmaisun täsmällisyys paranee. Keskityn laadullisissa havainnoissa sellaisiin transitiivikonstruktion variantteihin, jotka voi tulkita myös argumenttirakennekonstruktioiksi. Kotilainen (2007: 22) toteaa, että Ison suomen kieliopin (ISK 2004: 441) täydennysmuotti vastaa pitkälti Goldbergin (1995) argumenttirakennekonstruktiota: “[p]erusajatus on, että kieleen kuuluu paitsi verbejä ja näiden valenssin mukaisia täydennyksiä myös abstrakteja konstruktioita, jotka muuttavat verbin argumenttirakennetta.” Argumentit vastaavat pääpiirteissään Ison suomen kieliopin ns. pakollisia täydennyksiä (ISK 2004: 438-440; Västi 2012: 28). Iso suomen kielioppi (ISK 2004) mainitsee täydennysmuoteista yhtenä esimerkkinä resultatiivimuotin, jossa konstruktio sallii objektin sellaisiinkin verbeihin, joiden valenssiin se ei kuulu. Tällainen verbi on vaikkapa intransitiivinen hyppiä, jonka perusmerkitys on subjektitarkoitteen ylösalainen liike, joka voi johtaa tai olla johtamatta hyppijän paikan muuttumiseen. Verbin valenssiin kuuluu ainoastaan subjekti. ISK:n esimerkkilauseessa Maija hyppi veden pois korvastaan verbi saa kuitenkin sekä objektin että suuntasijaisen täydennyksen ja ilmaisee näin muutoksen aikaansaamista. Nämä argumentit ovat siis muotin mukanaan tuomia, ja muutoksen aikaansaamisen merkitys tulee siitä, että hyppiä-verbi esiintyy resultatiivimuotissa. (ISK 2004: 441.)

Iso suomen kielioppi (ISK 2004: 471) käsittelee muotteina myös joitakin sellaisia tapauksia, joissa täydennystä voi pitää verbin valenssiin kuuluvana, ei muotin aiheuttamana. Tällainen tapaus on olo- ja suuntasijaisissa muoteissa esimerkiksi asettamismuotin lokatiivinen täydennys panen kirjan pöydälle, jossa allatiivisijainen argumentti on panna-verbin 
edellyttämä. Kaikkein tiukimpien määritelmien (esim. Goldberg 1995) mukaan nämä valenssin mukaiset tapaukset eivät oikeastaan ole selviä argumenttirakennekonstruktioita, koska ne eivät muuta verbin argumenttirakennetta eli sitä, millaisia argumentteja verbi saa seurakseen. Käsittelen analyysissani kuitenkin ISK:n tapaan myös näitä tapauksia, sillä ne ovat vakiintuneita ilmausmalleja, joissa argumenttirakenne vaikuttaa olennaisesti ilmauksen kokonaismerkitykseen (vrt. Goldberg 2006). Tällaisten tapausten poisjättäminen myös rajaisi aineiston ulkopuolelle oppijankielen kehityksen kannalta kiinnostavia ilmaustyyppejä, jotka kertovat konstruktioiden verkoston laajentumisesta.

Määrittelen argumenttirakennekonstruktion siis melko väljästi sellaiseksi vakiintuneeksi konstruktioksi, joka koostuu verbistä ja sen argumenteista ja vaikuttaa verbin ja koko ilmauksen tulkintaan. Kuten Västi (2012: 28) toteaa, "[a]rgumentit ilmaisevat tyypillisesti tapahtuman keskeisiä osallistujia, joita ilman ei olisi kyse samasta tapahtumatyypistä". Erilaiset argumenttiympäristöt nostavat samastakin verbistä ja sen ilmaisemasta tapahtumasta esiin merkityksen eri puolia, jolloin ilmauksen kokonaismerkitys muodostuu konstruktion ja verbin yhteisvaikutuksesta (ISK 2004: 441). Esimerkki tällaisesta transitiivikonstruktiosta argumenttirakennekonstruktiona on ns. vaikuttamiskonstruktio, jossa objekti ilmaisee tavoitellun teon tekijän ja $M A$-infinitiivilauseke teon (ISK:n vaikuttamismuotti $\$ 479,474$ ): Pyysin Mikkoa auttamaan muutossa huomenna. Erilaisessa argumenttiympäristössä pyytääverbillisen transitiivi-ilmauksen merkitys olisi aivan toinen (esim. Pyysin tiskiltä kampasimpukoita.). Nähdäkseni tällaiset argumenttirakennekonstruktiot ovat vakiintuneisuutensa vuoksi luonteeltaan osa idiomaattista, kohdekielelle ominaista kielenkäyttöä ja osoittavat siten paitsi transitiivikonstruktion käytön monipuolistumista myös ilmaisun täsmentymistä oppijoiden kielessä.

Hyödynnän tarkastelussani ISK:n määrittelemiä muotteja (2004: 468-480). Katson tällaiset muotit kuitenkin tyypillisiksi konstruktioiksi, joten viittaan niihin konstruktioina. Konstruktion kielenkäytössä toteuttavia ilmauksia voidaan puolestaan nimittää konstrukteiksi 
(engl. construct, Fillmore \& Kay 1995: 2/15), mutta tässä artikkelissa viittaan aineistoni oppijankielen esimerkkeihin pääsääntöisesti toteutumina ja ilmauksina, joita siis käytän synonyymisesti.

\section{Tuloksia}

Tässä luvussa esittelen transitiivi-ilmausten kehitystä sekä määrällisesti että laadullisesti. Taustoitan laadullisia havaintoja esittelemällä ensin ilmausten taajuuden ja tarkkuuden taitotasoittain.

\subsection{Taajuus ja tarkkuus}

Kuviossa 1 näkyvät transitiivi-ilmausten $(n=1228)$ taajuus sekä norminmukaiset ja norminvastaiset käytöt eri taitotasoilla. Tässä yhteydessä on huomattava, että B2-tason lukuja ei voi pitää vertailukelpoisina muiden taitotasojen kanssa, sillä tämäntasoisia tekstejä on niin vähän (29 tekstiä, 2223 sanetta), ettei niiden perusteella voi tehdä luotettavaa määrällistä tarkastelua. Koululaisten mielipidekirjoitukset eivät yltäneet B1-tasoa korkeammalle.

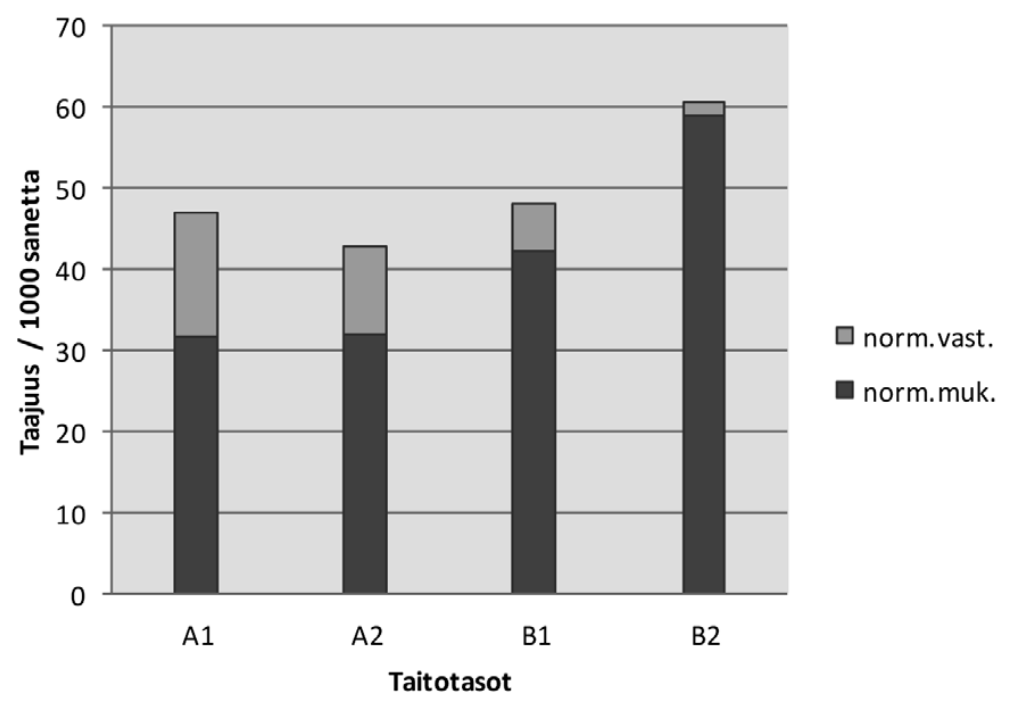

Kuvio 1. Yläkoululaisten kohdekielen mukaiset ja vastaiset transitiiviilmaukset kaikissa tehtävissä yhteensä (taajuus / 1000 sanetta) 
Kuten kuviosta 1 voi havaita, transitiivi-ilmausten taajuudessa on jonkin verran vaihtelua taitotasojen välillä (A2: 42,7; B2: 60,7). Khiin neliötestillä laskettuna erot eivät kuitenkaan ole tilastollisesti merkitseviä (Lesonen 2013: 39-41). Yläkoululaiset käyttävät transitiivi-ilmauksia melko tasaisesti A1-tasolta B1-tasolle. B2-tasolla taajuus näyttää kasvavan, mutta vähäisen tekstimäärän vuoksi tulokseen on syytä suhtautua varauksella. Myöskään tehtävittäin analysoituna (taulukko 2) taitotasojen välillä ei ole muita tilastollisesti merkitseviä eroja kuin tarinassa. Siinä B2-tasolla transitiivi-ilmauksia on merkitsevästi enemmän kuin muilla tasoilla ( $p$-arvo $<0,005^{\star *}$, Lesonen 2013: 41). Tuloksen luotettavuutta heikentää tosin kirjoitelmien vähäisyys.

TAULUкко 2. Yläkoululaisten transitiivi-ilmaukset tehtävittäin (taajuus / 1000 sanetta)

\begin{tabular}{|l|c|c|c|c|}
\hline \multirow{2}{*}{ Tehtävä } & \multicolumn{4}{|c|}{ Taitotaso } \\
\cline { 2 - 5 } & A1 & A2 & B1 & B2 \\
\hline Epämuodollinen viesti & 31,2 & 21,4 & 27,3 & 33,4 \\
\hline Muodollinen viesti & 57,1 & 68,0 & 71,3 & 77,1 \\
\hline Tarina & 49,3 & 43,6 & 39,6 & 74,5 \\
\hline Mielipide & 57,6 & 58,1 & 66,1 & - \\
\hline
\end{tabular}

Kun tarkastellaan frekvenssejä eri tehtävissä, huomataan, että käyttö kuitenkin vaihtelee tehtävien välillä (taulukko 2). Epämuodollisissa viesteissä kaverille ja opettajalle transitiivi-ilmauksia on selvästi vähemmän kuin muissa tehtävissä. Eniten transitiivikonstruktiota käytetään muodollisissa viesteissä ja mielipidekirjoituksissa, joissa ilmausten määrässä näyttää olevan loivasti kasvava tendenssi. Tarinoissa ilmausten määrä puolestaan laskee hieman A1-tasolta B1-tasolle. Epämuodollisten viestien vähäinen ilmausmäärä on varsin odotuksenmukainen ja johtunee tehtävänannoista. Etenkin viesteissä kaverille toteutumia on niukasti. Kun pitää perua sovittu tapaaminen, kertoa syy sekä ehdottaa uutta aikaa ja paikkaa, tehtävästä suoriutuu luontevasti ilman transitiiviilmauksia. Alla oleva 8.-luokkalaisen B1-tason viesti havainnollistaa tätä 
hyvin: esimerkissä ei ole yhtään nominiobjektillista transitiivi-ilmausta, mutta tehtävänanto ja siinä mainitut funktiot täyttyvät ongelmitta. Tekstissä on yksi lauseobjektillinen ilmaus (soitin sulle että menemme kahvilaan), mutta tällaiset tapaukset olen jättänyt tarkasteluni ulkopuolelle (ks. luku 2.2).

(1) Lähettäjä: Maija

Vastaanottaja: Kaisa

Aihe: en tule $::$

Moi Kaisa! Mitä kuuluu onks kaikki hyvin.

Kaisa eilen ku mä soitin sulle että menemme kahvilaan, sorry emmä voi tulla, koska meillä tule vierat Tanskasta ja ne on 3 paivää meillä. sovitaan niin etta menemme 3 päivän päästä. eli mennän launtaina, jos se sopi sulle? ok nähän launtaina hemsein kahvilassa kello 14.00.

T: Maija

$\left(\mathrm{emv} \mathrm{B} 1,{ }^{\star} 738\right)^{6}$

Vaikka frekvenssierot tasojen välillä kaikkiaan näyttävät pieniltä, transitiivi-ilmausten luottamusvälien analyysi ${ }^{7}$ (Lesonen 2013) on kuitenkin osoittanut, että eri tehtäviä tarkasteltaessa määrät poikkeavat jossain määrin toisistaan. Analyysin mukaan kaikissa tehtävissä A1- ja A2-tasot eroavat toisistaan ilmausten määrän suhteen: A1-tasolla toteutumia on vähemmän. A2- ja B1-tasot sen sijaan eroavat toisistaan vähemmän, ja eniten oppilaskohtaista vaihtelua määrässä on B1-tasolla. (Lesonen 2013: 41-44.) A1-tasolla transitiivi-ilmausten niukka käyttö ei ole yllätys: myös

\footnotetext{
6 Sulkeisiin on merkitty tehtävä, taitotaso sekä kirjoittajan tunnus. Tehtävien lyhenteet ovat seuraavat: $\mathrm{emv}=$ epämuodollinen viesti, $\mathrm{mv}=$ muodollinen viesti, $\mathrm{mp}=$ mielipide, $\mathrm{t}=$ tarina.

$7 \quad$ Kun lasketaan luottamusväliä, määritetään se väli, jolle keskiarvo sijoittuu 95 \%:n todennäköisyydellä. Luottamusväli on laskettu ns. Jackknife- eli leave-one-out-otannalla, jossa kukin kirjoitelma on poistettu aineistosta kerran ja jäljelle jääneistä on tarkasteltu transitiivi-ilmausten määrää. Uudelleenmuodostetusta otosjoukosta on laskettu varianssiarvo, jonka perusteella on laskettu luottamusväli. Jos eri tasojen luottamusvälit eivät mene päällekkäin, tasot eroavat todennäköisesti toisistaan ilmausten määrän osalta. Mitä pidempi luottamusväli taitotasolla on, sitä enemmän ilmausten määrä vaihtelee tason kirjoitelmien välillä. (Ks. Lesonen 2013: 23, 43.)
} 
aikuisilla objektiargumentti saattaa A-tasolla jäädä ilmaisematta (Martin ym. 2010: 69). Koska objektin läsnäolo on transitiivisuuden määritelmäni keskiössä, puuttuva objektiargumentti voi olla yksi selitys ilmausten vähäisyydelle. Kouluaineistossa transitiivi-ilmausten käyttö erottelee jo A1- ja A2-tasoja, kun taas aikuisilla se on A2- ja B1-tasoja erotteleva piirre (vrt. Lesonen 2013: 46; Martin ym. 2010: 68-69).

Ivaskan (2012) tekemän avainrakenneanalyysin perusteella aikuisilla transitiivisia lauseita ylipäätään on enemmän S1:ssä kuin S2:ssa. Tämän tutkimuksen aineistoa ei ole verrattu ensikielisiin koululaisiin, joten ei voida sanoa, näkyykö sama suuntaus nuorilla kirjoittajilla. Suuntaa-antavat taajuudet viittaavat siihen, että yläkoululaisten taidon kehittyessä transitiivi-ilmaukset eivät ainakaan kovin selvästi lisäänny. Käyttöpohjainen kielen oppimisen tutkimus on osoittanut, että lapset ja nuoret ovat erityisen herkkiä kieliympäristön frekvensseille (Newport 2014). Tämä herättää kysymyksen, onko kouluikäisten transitiiviilmausten taajuus lähempänä äidinkielisiä oman ikäisiä kuin aikuisilla. Melko tasainen käyttö eri taitotasoilla saattaisi antaa vihjeitä siitä, että koululaisten kielessä määrällinen ero S1-kirjoittajiin olisi aikuisia vähäisempi. On siis mahdollista, että S1- ja S2-kirjoittajien erot näkyvät selvemmin aikuisten kielessä, jossa konstruktion käyttö kasvaa - Cefling-aineistossa merkitsevästi - kielitaidon mukana ja lähestyy siten vähitellen S1-käyttöä (vrt. Martin ym. 2010: 68-69; Salmi 2010; Ivaska 2012; Lesonen 2013: 45-49).

Transitiivi-ilmausten tarkkuuden kehityksessä taitotasojen väliset erot eivät ole tilastollisesti merkitseviä (Lesonen 2013: 39), mutta suunta on selvä: ilmaukset tarkentuvat melko lineaarisesti taidon kehittyessä (kuvio 1). A1-tasolla kolmannes (33,5 \%) sijavalinnoista on norminvastaisia, kun taas B1-tasolla objektin sijavalinta on epäonnistunut enää $12 \%$ :ssa tapauksia. Aikuisilla suomenoppijoilla B1-tasolla norminmukaisia on n. $70 \%$ ja B2-tasolla puolestaan n. $86 \%$ ilmauksista (Martin ym. 2010: 69). Nuoret näyttävät siis saavuttavan esimerkiksi Cefling-hankkeen tutkimuksissa 80 prosentin kynnystasona pidetyn tarkkuuden yhtä taitotasoa aiemmin kuin aikuiset (vrt. myös Kajander 
2013). Vaikka objektin sijavalintaa pidetään usein oppijoille ongelmallisena ja vielä edistyneilläkin oppijoilla on satunnaisia objektivirheitä, tarkkuus kehittyy kuitenkin suotuisasti. Objektin sijavalinta lieneekin piirre, jonka omaksuminen vaatii aikaa ja altistusta kielelle. Nuoret käyvät koulua suomeksi ja käyttävät suomea usein aikuisia enemmän myös vapaa-aikana. Tällöin monipuolinen kohdekielinen ympäristö tarjoaa runsaasti kokemusta ja malleja ilmauksista. Tämä saattaakin olla yksi selitys sille, että objektin sijavalinta on kouluikäisillä norminmukaista yhtä taitotasoa aiemmin kuin aikuisilla. (Ks. myös Aalto ym. 2009: 410.)

\subsection{Laadullisia muutoksia: transitiivikonstruktion erilaiset argumenttiympäristöt}

Tässä luvussa esittelen transitiivikonstruktion käytön variaatiota erilaisissa argumenttirakenteissa EVK:n taitotasoilla: osa rakenteessa esiintyvistä argumenteista on ns. valenssinmukaisia täydennyksiä, osa konstruktion mukanaan tuomia. Nämä transitiivi-ilmaukset osoittavat, millaisiin argumenttiympäristöihin oppijat osaavat transitiivikonstruktiota soveltaa. Esittelen aineistoni konstruktioiden toteutumia yleisimmistä harvinaisempiin. Havainnollistan ilmiöitä esimerkeillä. Taustoitan käsittelyä tässä ensin lyhyesti muutamilla yleisillä huomioilla.

Yläkoululaisten transitiivi-ilmauksissa esiintyy jo A1-tasolla monenlaista variaatiota, kuten passiivia ja nollapersoonaa, alisteista ja rinnasteista käyttöä sekä erilaisia modaalisia käyttöjä (passiivista ja nollapersoonasta ks. Seilonen 2013). Argumenttiympäristöltään A1-tason ilmaukset ovat kuitenkin usein varsin yksinkertaisia, ja argumenttirakennekonstruktioiden toteutumia on kaikkiaan vähän. Alla oleva esimerkki 2 on A1-tasolle tyypillinen: aikaa ilmaisevien tai sellaisiksi tulkittavien adverbiaalien (aina, tunnilla, välitunnilla) lisäksi lauseissa ei ole muita laajennuksia.

(2) Koska ne aina häiritsivät tunnilla, mutta välitunnilla saa käytä kännykäitä. (mp A1, ${ }^{\star 200)}$ 
Siirtämistä ja asettamista ilmaisevat konstruktiot näyttävät kuitenkin olevan sellaisia, joita tehtävänantojen kontekstit ja tapahtumatyypit houkuttelevat. Näitä konstruktioita oppijat pyrkivätkin käyttämään jo A-tasolla - vaikkakaan eivät vielä välttämättä kaikilta osin aivan onnistu. Käsittelen siirtämistä ja asettamista lähemmin luvussa 4.2.1.

A2-tasolla argumenttirakennekonstruktioiden toteutumia esiintyy jo enemmän, mutta ilmauksissa ei ole välttämättä edelleenkään kovin paljon laajennuksia (esim. nominilausekkeita), kuten näkyy esimerkistä 3. A2-tason tarinasta poimitun virkkeen transitiivi-ilmaukset ovat malliesimerkkejä yläkoululaisille tavallisesta transitiivikonstruktion käytöstä.

(3) Sain silloin uuden pyörän ja halusin testata sitä, joten laskin alamäkeä, (jonka jälkeen tuli melkein heti roskakatos). (t A2, ${ }^{\star} 005$ )

Kielitaidon kehittyessä transitiivi-ilmausten argumenttiympäristöt monipuolistuvat. Jäljempänä luvussa 4.2.3 nostan esiin joitakin kiinnostavia mutta harvemmin käytettyjä argumenttirakennekonstruktioita. Kun ensimmäistä tunnistettavaa esiintymää pidetään jo osoituksena oppimisesta (ks. Martin ym. 2010: 59-60), tällaiset satunnaisemmatkin käytöt antavat viitteitä siitä, miten konstruktioiden verkosto laajenee: yksittäisiä ilmauksia alkaa ilmaantua prototyyppistä etäämmälle, ja verkosto laajenee ja tihenee. Aineistoni perusteella ei voi päätellä, edustaako harvinaisempi ilmaus oppijan ilmaisuvarantoon jo abstrahoitunutta konstruktiota vai onko ilmaus muistissa osin kiteytyneenä. Ilmaus kuitenkin kertoo siitä, että oppijankielessä alkaa tietyssä vaiheessa esiintyä myös harvinaisempia transitiivi-ilmauksia.

\subsubsection{Asettaminen ja siirtäminen, antaminen ja ottaminen}

Niin sanotut asettamis- ja siirtämiskonstruktiot ilmaisevat konkreettista tai metaforista sijainnin muutosta (ISK 2004: 471; engl. caused motion construction, Goldberg 1995: 152-179). Asettamiskonstruktion alatyyppinä voi puolestaan pitää ns. antamis- ja ottamiskonstruktioita, joilla ilmaistaan jonkin joutumista jonkun hallintaan (ISK 2004: 470-473, 
P. Leino 2001: 51-58). Oppijoiden kielestä on toisinaan vaikea yksiselitteisesti päätellä, minkä konstruktion toteutumana ilmausta voisi pitää, joten käsittelen yläkoululaisten asettamista, siirtämistä, antamista ja ottamista ilmaisevia transitiivi-ilmauksia tässä samassa alaluvussa.

Oppijat ilmaisevat asettamis- ja siirtämiskonstruktioilla tyypillisesti etenkin konkreettista sijainnin muutosta. Merkityksen konkreettisuus johtuu osin tehtävänannoista, mutta osin myös siitä, että varsinkaan A-tasolla kielitaito ei vielä riitä kovin käsitteellisistä asioista kirjoittamiseen (EVK 2003). Asettamis- ja siirtämiskonstruktioita käytetään kaikissa tehtävissä, mutta etenkin mielipidetetekstit aiheesta Kännykät pois koulusta! tuottivat runsaasti toteutumia kaikilla kolmella taitotasolla A1-B1. Esimerkiksi 4-7 aihe on konkreettinen ja liittyy läheisesti nuorille jokapäiväiseen asiaan, matkapuhelimen käyttöön koulussa. Myös muodollisissa viesteissä esiintyy näitä ilmauksia, kun kirjoittajat selvittävät verkkokaupasta tilatun tietokonepelin ongelmia (8 ja 9).

(4) koska täytty pois ja ääni laitta ääniton (mp A1, $\left.{ }^{\star 2} 204\right)$

(5) laila pois kannyka Se on sinulle hyvä asia. (mp A1, $\left.{ }^{\star} 060\right)$

(6) Minä lulen että ne ei saa poista mutta etta ne pistetais anetömale ja että niitä ei otetais ulos laukusta silloin kun on koulussa. (mp A2, ${ }^{\star} 033$ )

(7) Tai että kaikkien oppilaitten puhelimet laitettaisiin yhteen koriin. (mp B1, $\left.{ }^{\star} 739\right)$

(8) Minä olen ostanu (gta sanandreas) pelin, mutta sitä ei voi asenta tietokoneesen. ( $\left.\mathrm{mv} \mathrm{B} 1,{ }^{\star} 055\right)$

(9) Kun laitan peliin tietokoneseen, niin ensinäkin se ei asennu siihen. $\left(\mathrm{mv} \mathrm{B} 2,{ }^{*} 027\right)$

A1-tasolla oppijat pyrkivät ilmaisemaan paikanmuutosta, mutta ilmauksissa on monenlaista horjuntaa etenkin argumenttien sijamerkinnässä. Ilmaukset voi kuitenkin tunnistaa kokonaismerkityksensä perusteella jonkinlaisiksi asettamiskonstruktion toteutumiksi, vaikka esimerkiksi objektitarkoitteen paikanmuutosta ilmaiseva tulosija puuttuisikin, kuten esimerkissä 4: ääni laitta ääniton, po. äänettömälle/äänettömäksi. Saman esimerkin ensimmäisessä ilmauksessa koska täytty pois on lisäksi 
tulosijainen adverbi pois, joka myös ohjaa tulkintaa asettamisen suuntaan (ISK 2004: 471), vaikka ilmauksesta puuttuvat sekä asettamista ilmaiseva verbi että objekti. Myös esimerkissä 5 asettamiskonstruktiota osoittaa sama pois-adverbi. Esimerkin 4 kaltaisia objektittomia ilmauksia en ole ottanut mukaan määrälliseen tarkasteluuni, sillä ne olisivat tuottaneet aineiston valintaan liikaa tulkinnallisuutta. Tapaus on kuitenkin tyyppiesimerkki siitä, miten A1-tasolla argumentteja saattaa jäädä reaalistumatta. Samalla siitä näkyy oppijan pyrkimys ilmaista asettamista, vaikka kielitaidon rajoitteet estävätkin vielä konstruktiolle ominaisten argumenttien ilmaisemisen. Perustason alkuvaiheen oppijoilla näyttäisi siis olevan ilmaisutarvetta ja -yritystä huolimatta vielä osin puutteellisesta kielellisten keinojen valikoimasta.

A2-tason esimerkissä 6 toteutuvat sekä asettamis- että siirtämiskonstruktio ja konstruktioihin kuuluvat sijat ovat jo kohdekielen mukaiset (ne pistetais anetömale, niitä ei otetais ulos laukusta). Jälkimmäisessä transitiivi-ilmauksessa kirjoittaja käyttää siirtämiskonstruktion väylämerkitykselle ominaisesti sekä liikkeen lähtökohtaa ilmaisevaa erosijaista argumenttia laukusta että siirtämisen jälkeistä paikkaa ilmaisevaa tulosijaista adverbia ulos. A2- ja B1-tasoilla (esimerkit 6-8) asettamis- ja siirtämiskonstruktiot kuuluvat oppijoiden ilmaisuvarantoon jo laajasti. Muodollisissa viesteissä asettamis- ja siirtämisilmaukset ovat tavallisia esimerkkien 8 ja 9 kaltaisissa käytöissä: kirjoittaja selittää, miten on laittanut tai yrittänyt asentaa pelin tietokoneeseen tai -koneelle. A2-tasolta eteenpäin näiden konstruktioiden verbivalinnat alkavat myös vähitellen tarkentua. Laittamisen tai pistämisen sijaan konstruktiossa aletaan käyttää mm. tallentaa- ja asentaa-verbejä (esimerkki 8). Asettamis- ja siirtämiskonstruktioiden konkreettiset käytöt liittyvät paitsi tehtävänantoihin myös kielitaidon abstraktiotasoon, joka ei aineiston yläkoululaisilla ole vielä kaikilta osin kovin korkea (ks. funktioltaan konkreettisten ja abstraktien paikansijojen käytöstä EVK:n eri taitotasoilla Martin ym. 2010; Siivelt \& Mustonen 2013).

Asettamisen ja siirtämisen lisäksi mielipideteksteissä on toki jonkin verran myös vastaavia olosijaisen pitämiskonstruktion toteutumia 
(ISK 2004: 469), kun puhelimia pidetään auki, esillä tai moodilla (esimerkki 10). Näitä en kuitenkaan käsittele sen tarkemmin vaan keskityn yleisempiin asettamis- ja siirtämiskonstruktioihin.

(10) Nyt voi vaan pitää kännykkät silent moodilla, ja se ei häiritä tuntia enää. (mp A2, $\left.{ }^{\star} 030\right)$

Mielipidetekstin aihe matkapuhelinten käytöstä koulussa on omiaan tuottamaan kirjoitelmiin konkreettisia ja oppilaiden arkipäivässä paljon käytettyjä ilmauksia: melkein kaikissa teksteissä sekä perus- että keskitasolla puhelin laitetaan, pistetään tai pannaan äänettömälle/äänettömäksi/koriin/pois jne. Oppijoiden teksteissä ilmausten leksikaalinen variaatio näyttääkin osin suorastaan rajalliselta. Toisaalta tätä voidaan pitää myös idiomaattisen kielenkäytön osoituksena: oppimisympäristön vaikutus näkyy siinä, että tietyt yleiset ja toistuvat ilmaukset opitaan varhain ympäröivästä kielenkäytöstä ja niitä käytetään sellaisenaan suhteellisen sujuvasti alusta saakka (Ellis 2008: 373-374).

Yksi kiinnostava mielipideteksteissä näkyvä ilmiö on se, miten oppijat ottavat tehtävänannossa annetun otsikon käyttöönsä. Verbitöntä otsikkoa Kännykät pois koulusta! [X pois Y:stA] voisi itsessään pitää sellaisen argumenttirakennekonstruktion toteutumana, jossa toiminta tai tapahtuma ilmaistaan ilman verbiä (vrt. Västi 2012). Intuitiivinen merkitys äidinkieliselle puhujalle on jotakin sen tapaista kuin 'kännyköitä ei saa pitää/käyttää koulussa' tai 'kännykät tulisi kieltää koulussa'. Näin ollen otsikko ei siis edustaisi selvää elliptistä rakennetta, jossa verbi olisi vain jätetty ilmaisematta, vaan osa merkityksestä on nimenomaan konstruktion mukanaan tuomaa. Oppijat kuitenkin ottavat otsikon käyttöönsä sellaisenaan ja täydentävät puuttuvan verbin omissa teksteissään ennen muuta ottaa-verbillä (esimerkit 11-13).

(11) Kännykä saadan ota pois koulusta koska oppilat hairitsevat oppitunnilla. (mp A1, ${ }^{\star} 786$ )

(12) Mun mielestä jos otamme koulusta kännykät pois niin se olis ihan ärsyttävä. (mp A2, $\left.{ }^{\star} 026\right)$

(13) Kännykät on hyvä ottaa pois koulusta, jotta niitä ei varastettaisi. (mp B1, $\left.{ }^{\star} 303\right)$ 
Pois ja erosijainen argumentti näyttävät aktivoivan oppijoissa jonkinlaisen siirtämis- tai ottamiskonstruktion (ISK 2004: 471, 473). Lokatiivinen koulusta tuntuisi viittaavan aiheutettuun liikkeeseen, siirtämiseen, mutta yhtä uskottavana mallina voinee pitää myös siirtämiskonstruktion tavoin yleistä habitiivista ottamiskonstruktiota (S V O (pois) X:ltA). Siirtämisja ottamiskonstruktioilla on korkea tyyppifrekvenssi, mutta oppijoiden ottaa-verbin käyttöön vaikuttaa todennäköisesti tapausfrekvenssi (engl. token frequency, esim. Bybee 2008: 218-221). Sekä verbi että verbin ja adverbin muodostama yhtymä ovat hyvin tapausfrekventtejä: ottaa on suomen sadan yleisimmän sanan joukossa (esim. Kielipankki 2004), ja ottaa poiskin tuottaa satunnaishaulla yli 8000000 esiintymää Googlessa. Ottaa on myös ottamiskonstruktion prototyyppinen verbi. On siis mahdollista, että siirtämis-/ottamiskonstruktiota käytetään osin kiteytyneenä, leksikaalisesti täytettynä [ottaa X pois $\mathrm{Y}_{\text {ablat/elat }}$ ( (ks. Fillmore ym. 1988). Tällöin käyttöä voi pitää jossain määrin idiomin omaisena, vaikka ilmauksen merkitys ei näissä tapauksissa olekaan kontekstin kannalta kaikkein täsmällisin. Ottaa-verbiä käytetään niin A- kuin B-tasollakin (esimerkit 11-13).

Niin sanotun antamiskonstruktion toteuttavia ilmauksia yläkoululaiset käyttävät kaikilla taitotasoilla, eniten viesteissä opettajalle ja verkkokauppaan. Prototyyppisessä antamistapahtumassa on kolme pääjäsentä, ANTAJA, LAHJA ja SAAJA, joista antaja ja saaja ovat tyypillisesti henkilöitä (J. Leino 2001a: 67-68). Saaja ilmaistaan antamiskonstruktiossa (tai ANTAA-konstruktiossa: P. Leino ym. 2001; engl. ditransitive construction 'ditransitiivikonstruktio', Goldberg 1995) allatiivimuotoisella elementillä. Antamiskonstruktiolla voidaan kuitenkin ilmaista monenlaista omistus- tai hallintasuhteen siirtoa, ja konstruktiossa voi esiintyä myös sellaisia verbejä, joiden perusmerkitykseen ei kuulu antaminen (J. Leino 2001b: 220).

Seuraavat esimerkit ovat tyypillisiä antamiskonstruktion toteutumia aineistossa:

(14) he antoivat meille ruoka. (t A2, $\left.{ }^{\star} 045\right)$

(15) mä haluun että annat mulle uus peli kiitos. (mv A1, $\left.{ }^{\star} 063\right)$ 
(16) mina halua ota uusi peli ja anna sunlle vanha peli. (mv $\left.\mathrm{A} 1,{ }^{\star} 046\right)$

(17) Mutta minä haluan että te annatte minulle uusi peli. (mv A2, $\left.{ }^{\star} 735\right)$

(18) Ja nyt haluan tehdä niin, että minä palautan teille sen pelin ja te lähetätte minulle uuden, ja kun se ei toimi myös, sitten haluan rahat takaisin. (mv B1, ${ }^{\star} 730$ )

(19) Haluaisin ystävällisesti pyytää, että antaisitte mahdollisuuden palauttaa pelin teille takaisin, ja että peliä korjataan, että sillä voisi pelata. (mv B1, $\left.{ }^{\star} 788\right)$

A2-tason tarinassa (esimerkki 14) kirjoittaja kertoo lentomatkastaan, jonka aikana tarjottiin ruokaa. He viittaa lentoemäntiin, ja käyttö on malliesimerkki prototyyppisen antamiskonstruktion toteuttavasta transitiivi-ilmauksesta. Varsinkin A1-tasolla oppijat käyttävät ilmauksissaan usein juuri konstruktiolle prototyyppistä antaa-verbiä. Se on kuitenkin monessa tapauksessa merkitykseltään tilanteeseen turhan yleinen ja epämääräinen, kuten A1- ja A2-tason esimerkeissä 15, 16 ja 17. Esimerkiksi verkkokauppaviesteissä täsmällisempiä verbejä olisivat vaikkapa lähettää, toimittaa tai palauttaa. A2-tasolla antaa-verbiä käytetään verkkokauppaviesteissä jo vähemmän, ja B1-tasolla sen ovat korvanneet kokonaan muut, eksplisiittisemmät verbit (esimerkit 18 ja 19).

Pentti Leino (2001: 55) mainitsee, että ANTAA-konstruktion kanssa samaa allatiivijäsenen sisältämää syntaktista konstruktiota noudattavat myös sellaiset verbit, joissa annettavana on esimerkiksi tieto, jonka saaja saa mutta joka jää edelleen myös antajan haltuun. Tällaisia tapauksia ovat esimerkiksi sähköpostin lähettämiseen viittaavat ilmaukset, joiden merkitys on pikemminkin 'saattaa tietoon/tiedoksi' kuin 'saattaa haltuun'. Näitä konstruktion toteutumia on etenkin muodollisessa viestissä ja viestissä opettajalle, jotka viesteinä ja tehtävänannoiltaan luovat odotuksenmukaisesti konstruktiolle otollisen kontekstin (esimerkit 20 ja 21). Seuraavissa esimerkeissä antamiskonstruktiota käytetään juuri yllä olevassa merkityksessä:

(20) lähetiin teille [verkkokauppaan] moneta kerataa sähköposti mutt tää verkkokaupa on huono $\left(\mathrm{mv} \mathrm{A} 1,{ }^{\star} 703\right)$ 
(21) Olisi kiva jos voisit lähettää minulle sivut mistä voisin lukee naitä mitä olette käyneet läpi, kun en ollut koulussa. (emv B1, ${ }^{\star} 801$ )

(22) Töissä on ihmiset, niiden pitää aina soittaa ja ilmoittaa asioita toiselle ihmiselle ja kännykkä on tärkeä ihmisille. (mp B1, ${ }^{\star} 766$ )

Esimerkin 20 voisi tulkita ehkä myös siirtämistä ilmaisevaksi, sillä siinä viestiä ei ole suunnattu suoraan kenellekään tietylle henkilölle vaan teille viittaa ennemminkin verkkokauppaan. Tällöin vastaanottaja tai viestin metaforinen "paikka" olisikin lokatiivinen (kauppaan) eikä habitiivinen. Lähettää-verbi voi esiintyä sekä lokatiivisena että habitiivisena, joten antamis- ja siirtämiskonstruktioiden raja ei ole näissä tapauksissa kovin selvä. Selvemmin antamisen kaltaiseksi hahmottuu esimerkin 21 ilmaus, joka on kohdistettu opettajalle. Oppilas pyytää opettajaa lähettämään hänelle tiedot läksyistä. B-tasolla myös tiedonantoa ilmaisevien verbien valikoima alkaa kasvaa: mielipidetekstistä poimitussa esimerkissä 22 oppilas käyttää konstruktiossa kommunikaatioverbiä ilmoittaa.

Antamiskonstruktion rakennetta noudattaa myös ns. hyötyjäkonstruktio. Muodollisessa viestissä isoveli on tilannut kirjoittajalle verkkokaupasta pelin, jossa on jotakin vikaa. Kirjoittajan pitää lähettää aiheesta sähköpostiviesti, jossa hän selvittää ongelman ja esittää ratkaisuehdotuksen. Jo itse tehtävänannossa esiintyy hyötyjäkonstruktion toteutuma Isoveli on tilannut sinulle verkkokaupasta tietokonepelin. Hyötyjäkonstruktio edustaa samaa syntaktista konstruktiota kuin antamiskonstruktio, mutta näkökulmassa keskeistä on se, että objektin tarkoite on tarkoitettu elollisen olennon hyväksi (ISK 2004: 473): muodollisessa viestissä peli on tilattu siis nimenomaan pikkusisarukselle. Onkin aivan odotuksenmukaista, että oppijat käyttävät hyötyjäilmauksia A1-tasolta alkaen. He osaavat hyödyntää ja kierrättää tehtävänannon muotoilua viesteissään kaikilla taitotasoilla (esimerkit 23-27).

(23) mun isoveli osti mulla tietokonepeli ( $\mathrm{mv} \mathrm{A} 1,{ }^{\star} 063$ )

(24) Eilen mun veli osti mulle pelin joka toimii huonosti. (mv A1, ${ }^{\star} 008$ )

(25) Minä kirjotan koska minun Iso veli on tillannut minulle verkkokaupasta tietokonepelli ja peli toinii huonosti. (mv A2, $\left.{ }^{\star} 715\right)$ 
(26) Minä olen Maija Solki ja mun isoveli oli tilannut minulle pari päivää sitten yhden pelin. ( $\left.\mathrm{mv} \mathrm{B1},{ }^{\star} 007\right)$

(27) Veljeni tilasi minulle verkkokaupasta nhlxxxx tietokone pelin. (mv $\left.\mathrm{B} 2,{ }^{*} 797\right)$

Yllä olevan kaltaisia ilmauksia voisi pitää tehtävänannon kopioimisena, mutta esimerkit osoittavat, että kirjoittajat eivät juurikaan käytä tehtävän muotoilua sellaisenaan. Kierrättäessään kieltä he myös muokkaavat sitä (ks. esim. Lynch \& Maclean 2000). Yksi osoitus siitä, että oppijat ovat ottaneet instruktiossa esiintyvän ilmauksen ns. itsenäiseen ja produktiiviseen käyttöön, on sijavalinnan horjunta. A1-tason esimerkissä 23 sekä objektin että habitiivisen argumentin sijavalinta on norminvastainen. Myös esimerkissä 25 objekti on genetiivin sijaan nominativissa. Ilmauksissa 23 ja 24 oppijat ovat muuttaneet tehtävänannon muotoilua puhekielisemmäksi (mun (iso)veli, mulla/mulle). Äidinkielisten koululaisten tavoin myös oppijat käyttävät teksteissään paljon puhekieltä resurssina (ks. myös Halonen 2009; Kalliokoski 2008): muodollisessa viestissäkin puhekielisen rekisterin käyttö tai horjunta rekisterien välillä on tavallista vielä B1-tasolla (26). B2-tasolla muodollinen ja epämuodollinen rekisteri alkavat selvemmin eriytyä (27). Muodollisissa viesteissä tehtävänanto toimii oppijoille merkityksellisenä resurssina. Suni (2008) on pohtinut toistoja ja kielen jaettuutta toisen kielen oppimisessa ja tarjoaa näkökulman toistoon kielellisten resurssien jakamisena: osaamattomuuden sijaan toistot ja kieliaineksen kierrättäminen - kuten tässä tehtävänannon hyödyntäminen - ovatkin pikemmin voimavara kuin "kopiointia" (Suni 2008: 186-187).

\subsubsection{Vaikuttaminen ja suuntautuminen}

Yksi kiinnostava transitiivikonstruktion variantti, joka esiintyy oppijoiden kirjoitelmissa kaikilla taitotasoilla, on ns. vaikuttamiskonstruktio. Vaikuttamiskonstruktiossa objekti ilmaisee tavoitellun teon tekijän ja MA-infinitiivilauseke teon (ISK 2004: 474). Vaikka konstruktiota voi pitää infinitiivirakenteen vuoksi syntaktisesti jo vaativampana, oppijoilla 
on yritystä käyttää sitä A1-tasolta alkaen. Yläkoululaisten vaikuttamiskonstruktion käyttö ei kytkeydy suoraan mihinkään tehtävänantoon, vaan toteutumia on kaikissa tehtävissä. Esimerkit 28-35 valottavat käyttöä eri taitotasoilla.

(28) Mun käveri oli pakottanyt minä pelaa ( $\left.\mathrm{A} 1,{ }^{\star} 725\right)$

(29) sitten meniin taas tornado ja täälä kerta mun kaverit pakotetiin mut mennä Half Pife (t A2, ${ }^{\star} 063$ )

(30) Äiti pyysi minua hakemaa läkkeet kotoa kello kaksi. (t A2, ${ }^{\star} 002$ )

(31) Koska mun äiti pyys minua autamaa. (t, B1*040)

(32) Hei, Minun veli oli tilannut tämän peli minulle eilen, ja en ole saanut sitä toimimaan. ( $\left.\mathrm{mv} \mathrm{B} 1,{ }^{\star} 816\right)$

(33) Olin joukkueen paras vetäjä, eli minut laitettiin potkasemaan. (t B1, *756)

(34) Pyydän teitä vaihtaa pelin, jos on mahdollista tai antaa rahat takaisin. $\left(\mathrm{mv} \mathrm{B} 2{ }^{\star} 707\right)$

(35) No, olin onneksi herännyt puoli tuntia myöhässä heräämisajasta, kiitos ystävieni jotka olivat tulleet herättämään minua ja he passittivat minut valmistautumaan ja ehdimme hyvissä ajoin kouluun! (t B2, *711)

A-tasolla vaikuttamiskonstruktion toteutumat ovat hyvin satunnaisia (esimerkit 28-30), mutta niitä kuitenkin esiintyy. Etenkin tällä perustasolla konstruktiossa saatetaan kuitenkin käyttää $M A$-infinitiivin sijaan enemmän muita verbimuotoja $(28,29)$. Muutenkin tarkkuus voi horjua. Tästä huolimatta ilmaukset ovat selvästi tunnistettavissa vaikuttamiskonstruktion toteutumiksi. Esimerkissä 28 pelaa näyttää yksikön kolmannelta persoonalta, mutta yhtä hyvin se voi olla yksikön ensimmäinen persoona (pelaan), jonka loppu- $n$ on jäänyt pois, kuten puheessa usein käy. Tätä tulkintaa tukee myös oppijan persoonapronominin muoto mä. Myös MA-infinitiivin puhekielinen muoto (esim. ne pyys mua pelaan jalkapalloo) on voinut toimia mallina verbimuodolle. On mahdollista, että oppija on omaksunut rakenteen puheesta ja käyttää siksi kuulemaansa muotoa konstruktiossa. Esimerkissä $29 M A$-inifinitiivin tilalla on puolestaan $A$-infinitiivi. Monet suomen verbit saavat $A$-infinitiivin täydennyksekseen, joten oppijat yliyleistävät muodon käytön helposti 
(vrt. Seppälä 2013). B-tasolla vaikuttamiskonstruktio kuuluu jo enenevästi oppijoiden resursseihin (esimerkit 31-35) ja myös konstruktiossa esiintyvät vaikuttamisverbit varioivat enemmän.

Edellä oleva A2-tason ilmaus 30 on myös malliesimerkki siitä, miten kielenkäytössä ilmaukset toteuttavat useita konstruktioita samanaikaisesti. Oppijan tarinasta poimitussa ilmauksessa toteutuvat vaikuttamiskonstruktio, erosijainen asettamiskonstruktio (hakea jotain jostakin) sekä tietysti myös transitiivikonstruktio. Esimerkki havainnollistaa myös sitä, miten oppijat käyttävät aiemmin käsiteltyjä asettamis- ja siirtämiskonstruktioita muissakin tehtävissä kuin mielipiteessä ja muodollisessa viestissä.

$M A$-infinitiivilauseke sisältyy myös ns. suuntautumiskonstruktioon, jossa inifinitiiviä käytetään mentaalista tai sosiaalista asiaintilaa ilmaisevan verbin kanssa. Konstruktio edustaa samaa tyyppiä kuin asettumismuotti. Joidenkin verbien kohdalla $M A$-infinitiivin käyttö on rektion luonteista. (ISK 2004: 463, 474.) Suuntautumiskonstruktioon itseensä ei kuulu objektia, mutta transitiivikonstruktio voi toteutua infinitiivilausekkeessa. Olen ottanut tällaiset ilmaukset mukaan analyysiini, sillä ne osoittavat kuitenkin käytön variaatiota siltä kannalta, millaisissa yhteyksissä transitiivikonstruktio yläkoululaisten oppijansuomessa voi toteutua. A1-tasolla näitä suuntautumisilmauksia ei ole, mutta A2-tasolta eteenpäin niitä alkaa ilmaantua oppijoiden kirjoitettuun kieleen. Suuntautumiskonstruktioissa käytetään lähinnä päästä-verbiä $(37,38)$ sekä jonkin verran myös päästää-verbiä (39). Muita satunnaisesti esiintyviä verbejä ovat esimerkiksi oppia ja joutua (36).

(36) Minä joudun perumaan meidän tapamisen koska minulla on tosi tarkea peli. $\left(\mathrm{emv} \mathrm{A} 2,{ }^{\star} 033\right)$

(37) Liikunnan tunti on hauska koska siellä pääse pelaaman kavereiden kanssa sählyä, koripalloa ja jalkapalloa. (t A2, $\left.{ }^{\star} 055\right)$

(38) En usko, etta pääsen sinä päivanä tekemään suomen kielen koetta. (emv B1, $\left.{ }^{\star} 799\right)$

(39) Äiti sanoi niin, että minä en mene bussiin, eikä päästä menemään ketään muuta. $\left(\mathrm{t} \mathrm{B1},{ }^{\star} 730\right)$ 
Vastaavan tyyppisiä ovat myös muut $M A$-infinitiivilausekkeissa toteutuvat transitiivikonstruktion käytöt, kuten olosijaisen pistäytymiskonstruktion (ISK 2004: 469-470) toteutumat. Näitä esiintyy oppijoiden teksteissä jonkin verran kaikilla taitotasoilla A1-tasoa lukuun ottamatta.

(40) Lähin viikoksi ulkomaille siellä kävin kattomassa tuttuja. (emv A2, *702)

(41) Tulen huomenna käymään palauttamassa pelin, ostan uuden tilalle uuden samanlaisen. $\left(\mathrm{mv} \mathrm{B1},{ }^{\star} 794\right)$

\subsubsection{Muita transitiivikonstruktion käyttökonteksteja}

Lopuksi nostan hyvin lyhyesti esiin vielä muutaman muun, aineistossa satunnaisesti esiintyvän transitiivi-ilmauksen argumenttiympäristön. Nämä argumenttirakennekonstruktioiden toteutumat antavat viitteitä siitä, miten yksittäisiä harvinaisempia, transitiivikonstruktion prototyyppisestä käytöstä etäämmällä olevia käyttöjä alkaa ilmaantua oppijoiden kielellisiin resursseihin.

Resultatiivikonstruktion (ks. myös Goldberg 1995: 80-89; engl. resultative construction) toteutumia on aineistossa vain muutama. Ison suomen kieliopin (ISK 2004: 477) mukaan "resultatiivimuotti ilmaisee subjektitarkoitteen aikaansaamaa muutosta, jonka ansiosta objektin tarkoite on adverbiaalitäydennyksen tarkoittamassa paikassa tai tilassa": ao. esimerkissä 42 kertojan tilauksen jälkeen reppu on täynnä limua. Vaikka tilata on transitiiviverbi, objektiargumentin (reppu) läsnäolo ei perustu tässä verbin transitiivisuuteen vaan konstruktioon. Sikäli kyseessä on tiukimpienkin määritelmien mukaan selvä argumenttirakennekonstruktio.

(42) tilasin reppu täyteen limua ( $\left.\mathrm{A} 2,{ }^{\star} 723\right)$

Yksittäisiä tapauksia ovat myös arviointia ja luokittelua ilmaisevan ns. arviointikonstruktion toteutumat. Näitä ilmaantuu teksteihin vasta B-tasolla. Konstruktiossa sekä objekti että predikatiiviadverbiaali voivat molemmat olla välttämättömiä, koska muissa käytöissään verbi ei aina 
saa kyseisen tyyppistä objektia (ISK 2004: 480-481). Tällainen tapaus on alla oleva esimerkki 43: *kutsua jotakuta (merkityksessä 'käyttää jostakusta nimitystä) ei ole mahdollinen ilman predikatiiviadverbiaalia (Solkiksi).

(43) Meidän teoria ope on muuten kiva, mutta se kutsu mua Solkiksi. $\left(\mathrm{t} \mathrm{B1},{ }^{\star} 031\right)$

Yksi harvinainen, vasta B2-tasolla ilmaantuva konstruktio, on ns. erottamattoman omistuksen konstruktio. Objekti viittaa olioon, jonka osasta on kyse, ja suuntasijaisella adverbiaalilla taas ilmaistaan osaa, johon tartutaan tai kosketaan. Konstruktiossa esiintyvistä verbeistä tyypillisimpiä ovat juuri partitiiviobjektin saavat kontaktiverbit. (ISK 2004: 460-461.) Koululaisten tarinoissa esiintyviä verbejä ovat purra, lyödä ja hakata.

(44) Menin nopeasti hänen luokseen auttamaan häntä, mutta koira oli jo todella lähellä ja puri häntä jalkaan. (t B2, *806)

(45) Yhtäkkiä hän löi mua päähän ja sai pisteen. (t B2, *816)

Harvinaisempia argumenttirakennekonstruktioiden toteutumia on ainoastaan tarinoissa. Muissa tehtävissä tehtävänantojen kontekstit saattavat kuvata tarkemmin tilanteen ja tapahtuman, jotka aktivoivat kirjoittajan kognitiossa kehyksiä ${ }^{8}$, joita kielennetään vakiintuneilla konstruktioilla. Tarina kuitenkin mahdollistaa hyvin vaihtelevien tapahtumien ilmaisemisen, mikä selittänee osaltaan harvinaisempien ilmausten keskittymisen juuri tarinatehtävään. Toisaalta oppijat käyttävät näitä ilmauksia tarinoissakin pääsääntöisesti vasta B-tasolla, joten A-tason kirjoittajien ilmaisuvarantoon ne eivät tyypillisesti tuntuisi kuuluvan.

\footnotetext{
8 Viittaan tässä kehyksellä semanttiseen kehykseen (tai tapahtumatyyppiin; scene), joka on mielikuvaskeema, johon tapahtuma sijoitetaan. Esimerkiksi antamiskehys on prototyyppisen antamistapahtuman kuvaava ideaalistus, jossa on kolme pääosallistujaa: antaja, lahja ja saaja. (Esim. J. Leino 2001a: 71-72; 2010: 74-76.) Esimerkiksi muodollisen viestin tehtävänannossa itsessään on jo kuvattu antamistapahtuma. Myös mahdollinen pelin palauttaminen ja uuden saaminen tarjoavat antamiskehykselle otollisen kontekstin.
} 


\section{Lopuksi}

Tässä artikkelissa olen tarkastellut sitä, miten yleisen ja monikäyttöisen ilmausmallin, transitiivikonstruktion, toteutumat kehittyvät yläkoululaisten kirjoitetussa oppijansuomessa. Ilmauksia käytetään kaikilla tutkituilla taitotasoilla (A1-B2) varsin yleisesti. Erot ilmausten taajuudessa taitotasojen välillä eivät ole kovin suuria, mutta joitakin kehityssuuntia määrissä voi havaita. Luottamusvälianalyysin perusteella A1- ja A2-tasojen välillä eroja kuitenkin on, vaikka ne eivät frekvensseissä suoraan näykään. A1-tasolla transitiivi-ilmauksia on kaikkiaan vähemmän, sillä tasolle on tyypillistä, että ns. pakollisetkin argumentit - kuten objekti voivat jäädä ilmaisematta. Tehtävittäin ilmausten käyttö vaihtelee selvemmin. Varsinkaan epämuodollisessa viestissä tehtävänanto ei tunnu houkuttelevan transitiivi-ilmauksia, ja niitä esiintyykin teksteissä vähän. Mielipideteksteissä ja muodollisissa viesteissä ilmauksia sen sijaan on kaikilla taitotasoilla selvästi runsaammin.

Käyttöpohjaisessa kielentutkimuksessa on havaittu, että oppijat ovat herkkiä kieliympäristön tilastolliselle vaihtelulle. Systemaattista kieltä syntyy, vaikka ympäristön kielessä olisi variaatiota ja epäjohdonmukaisuutta. On viitteitä siitä, että lapset ja nuoret ovat aikuisia herkempiä frekvenssien vaihtelulle. (Esim. Newport 2014.) Taitotasoittain vähäinen vaihtelu saattaa tukea tätä käyttöpohjaisen oppimisen näkökulmaa: nuorilla oppijoilla ilmausten taajuus on mahdollisesti alusta asti lähempänä äidinkielisten ilmausten taajuutta kuin aikuisilla oppijoilla.

Transitiivi-ilmausten tarkkuus kehittyy odotuksenmukaisesti. Usein oppijoille haastavana pidetty objektin sijavalinta on norminmukaista jo B1-tasolla, yhtä taitotasoa varhemmin kuin aikuisilla. B1-tasolla norminmukaisten muotojen osuus on jo liki $87 \%$. B2-tasolle arvioituja tekstejä on yläkouluaineistossa niin vähän, että luotettava määrällinen tarkastelu ei ole mahdollista. Näissä 29 tekstissä objektin sijavalinta on kuitenkin oikein peräti $97 \%$ :ssa tapauksia.

Määrällisen tarkastelun perusteella nuorten transitiivi-ilmausten käytössä ei ole kovinkaan selviä eroja taitotasojen välillä. Laadullinen 
tarkastelu puolestaan tarjoaa täsmällisemmän kuvan transitiivi-ilmausten käytöstä. Transitiivikonstruktio on yleisyytensä ja monikäyttöisyytensä vuoksi otollinen tutkimuskohde sen selvittämiseen, miten lausetason ilmaisun peruskeinot (ks. Västi 2012: 43-44) - argumenttirakennekonstruktiot ja niiden omaiset muut vakiintuneet konstruktiot - ilmaantuvat oppijankieleen. Transitiivi-ilmausten erilaisten argumenttiympäristöjen tarkastelu liittyy myös suomen paikallisijojen käytön kehitykseen (esim. Lauranto 1997; Martin ym. 2010; Määttä 2011; Siivelt \& Mustonen 2013), mutta tutkimukseni näkökulma on pikemminkin laajempien, lausetason ilmausmallien kehittymisessä. Tyypillisesti transitiivikonstruktio yhdistyy oppijankielen kehityksen alkuvaiheista asti erilaisiin siirtämistä, asettamista, antamista ja ottamista ilmaiseviin konstruktioihin. Tietyt aineiston tehtävänannot tuntuvat vetävän näitä ilmauksia puoleensa, mikä saattaa selittää ainakin osittain myös eri tehtävien välisiä määrällisiä eroja: muodollisessa viestissä ja mielipiteessä transitiivi-ilmauksia on eniten, ja näissä tehtävissä myös asettamis- ja siirtämiskonstruktioita käytetään tavallisimmin. Mainittuja konstruktioita käytetään kielessä myös muutoin laajasti, joten sikälikään ei ole yllättävää, että ne myös omaksutaan suhteellisen varhain. Vaikka tehtävien vaikutus argumenttiympäristöihin on ilmeinen, neljä erilaista tehtävää kuitenkin monipuolistavat kuvaa transitiivi-ilmausten kehityksestä. Esimerkiksi asettamis- ja siirtämiskonstruktioiden toteutumia esiintyy jonkin verran kaikissa tehtävissä. A1-tasolla argumenttiympäristöt eivät ole vielä kovinkaan monipuolisia, mutta näitä yleisimpiä konstruktioita oppijat pyrkivät jo jossain määrin käyttämään tehtävänantojen edellytysten mukaisesti.

Ilmausten korkea tyyppifrekvenssi vahvistaa yleistyksen eli konstruktion muodostumista oppijan mielessä (Ellis 2002; 2008; Bybee 2008). Aineistossa on kuitenkin havaittavissa viitteitä myös joidenkin ilmausten käytöstä kiteytyminä. Vaikka ilmausten leksikaalinen variaatio saattaa näyttää vähäiseltä, se ei ole kuitenkaan aina merkki kielitaidon puutteista. Useat tällaiset sanastoltaan vaihteluttomat ilmaukset ovat kontekstissaan luontevia ja idiomaattisia. Kielenkäytöstä on opittu yleisiä ja 
suomen kielelle ominaisia ilmaisutapoja. Varsinkin antamiskonstruktiossa A1-tason oppijat käyttävät pitkälti prototyyppisiä verbejä, mutta A2-tasolla ja etenkin B-tasolla myös verbien variaatio lisääntyy. Oppijoiden teksteissä transitiivi-ilmaukset ovat merkitykseltään pääosin melko konkreettisia, mikä johtunee niin tehtävänannoista, oppijoiden kielitaidon tasosta kuin heidän iästäänkin: nuoret kirjoittavat lyhyitä ja arkipäiväisiä tekstejä itselleen tutuista aiheista. Tämä kuuluu myös EVK:n mukaan A1-B1-tasojen viestinnälle tyypillisiin piirteisiin (EVK 2003, ks. myös Siivelt \& Mustonen 2013 sekä Kajander 2013).

Käyttöpohjaisen konstruktiokieliopin näkökulma valottaa oppijoiden kielellisten resurssien kehitystä ja ohjaa myös kiinnittämään huomiota ympäröivän kielen rooliin oppimisessa. Ympäristöstä omaksuminen näkyy nuorilla: kaikkein tavallisimmat ilmaukset ovat melko varhain käytössä argumentteineen. Samoin kielen kierrättäminen osoittaa kykyä hyödyntää kaikkea ympäröivää kieliainesta. Kielisysteemin järjestäminen alkaa usein prototyypistä käsin, ja vähitellen monipuolistuvat argumenttiympäristöt osoittavat prototyyppisen käytön laajentumista. Harvinaisempia, syntaktisesti haastavampia ja prototyyppisestä transitiivikonstruktiosta etäämpänä olevia argumenttirakennekonstruktioita alkaa ilmaantua käyttöön yksittäisinä toteutumina. Erilaisten yleisempien argumenttiympäristöjen kanssa ne kaikki kertovat oppijoiden syntaktisten resurssien ja samalla ilmaisun täsmällisyyden kasvusta. Ei ole todennäköistä, että tutkittuja ilmauksia prosessoidaan sana sanalta, vaan ainakin jossain määrin ehkä juuri isompina kokonaisuuksina, argumenttirakennekonstruktioina tai valmiina, osin leksikaalistuneina konstruktioina. Opetuksessakin tulisi pyrkiä jäsentämään ympäröivän kielen ilmauksia ja tarjota oppijoille välineitä hahmottaa laajempia kielellisiä kokonaisuuksia. Altistus kielelle, valmiit fraasit ja kokonaiset ilmaukset tarjoavat aineksia yleistysten syntymiselle, mutta myös ilmausten tarkastelu argumenttirakennekonstruktioina (ks. Tyler 2012) voisi ohjata oppijoita havaitsemaan ja käyttämään ilmauksia erilaisissa argumenttiympäristöissä ilmaisutarpeidensa mukaisesti. 


\section{Kiitokset}

Tutkimusta ovat rahoittaneet Suomen Akatemia, kielentutkimuksen tohtorikoulu Langnet, Jyväskylän yliopiston kielten laitos sekä Ellen ja Artturi Nyyssösen säätiö.

\section{Lähteet}

Aalto, Eija, Sanna Mustonen, Kaisa Tukia 2009. Funktionaalisuus toisen kielen opetuksen lähtökohtana. - Virittäjä 113 (3), 402-423.

Ånäs, Aurora 2008. Yksi- ja kaksikielisten suomenruotsalaisten sijanvalinta objektitestissä. Pro gradu -tutkielma. Turun yliopiston suomalaisen ja yleisen kielitieteen laitos, suomen kieli.

Aslin, Richard N., Elissa L. Newport 2012. Statistical learning: From acquiring specific items to forming general rules. - Current Directions in Psychological Science 21 (3), 170-176. http://dx.doi.org/10.1177/0963721412436806

Bybee, Joan L. 1985. Morphology: A Study of the Relation Between Meaning and Form. Amsterdam, Philadelphia: John Benjamins. http://dx.doi. org/10.1075/tsl.9

Bybee, Joan L. 2006. From usage to grammar: The mind's response to repetition. Language 82 (4), 711-733. http://dx.doi.org/10.1353/lan.2006.0186

Bybee, Joan L. 2008. Usage-based grammar and second language acquisition. Peter Robinson, Nick C. Ellis (Eds.). Handbook of Cognitive Linguistics and Second Language Acquisition. New York: Routledge, 216-236.

Bybee, Joan L. 2010. Language, Usage and Cognition. Cambridge: Cambridge University Press. http://dx.doi.org/10.1017/CBO9780511750526

Ellis, Nick C. 2002. Reflections on frequency effects in language processing. Studies in Second Language Acquisition 24 (2), 297-339.

Ellis, Nick C. 2003. Constructions, chunking, and connectionism: The emergence of second language structure. - Catherine J. Doughty, Michael H. Long (Eds.). The Handbook of Second Language Acquisition. Oxford: Blackwell Publishing, 63-103.

Ellis, Nick C. 2008. Usage-based and form-focused language acquisition. The associative learning of constructions, learned attention, and the limited L2 endstate. - Peter Robinson, Nick C. Ellis (Eds.). Handbook of Cognitive Linguistics and Second Language Acquisition. New York: Routledge, $372-405$. 
EVK = Eurooppalainen viitekehys. Kielten oppimisen, opettamisen ja arvioinnin yhteinen eurooppalainen viitekehys 2003. Helsinki: WSOY.

Fillmore, Charles J., Paul Kay, Mary C. O’Connor 1988. Regularity and idiomaticity in grammatical constructions. - Language 64 (3), 501-538. http:// dx.doi.org/10.2307/414531

Fillmore, Charles J., Paul Kay 1995. Construction Grammar. CSLI Lecture Notes. Center for the Study of Language and Information. Stanford, CA. (Manuscript.)

Goldberg, Adele E. 1995. Constructions: A Construction Grammar Approach to Argument Structure. Chicago: University of Chicago Press.

Goldberg, Adele E. 2006. Constructions at Work. The Nature of Generalization in Language. New York: Oxford University Press.

Goldberg, Adele E., Laura Suttle 2010. Construction grammar. - Wiley Interdisciplinary Reviews: Cognitive Science 1 (4), 468-477. http://dx.doi. org/10.1002/wcs.22

Graf, Eileen, Anna L. Theakston, Elena V. M. Lieven, Michael Tomasello 2014. Subject and object omission in children's early transitive constructions: A discourse-pragmatic approach. - Applied Psycholinguistics, FirstView Article, 1-27. Published online 27 January 2014. http://dx.doi.org/10.1017/ $\underline{\text { S0142716413000477 }}$

Göken, Ina 2012. “Tiedän mik- mitä sana tarkoittaa." Suomea toisena kielenä puhuvien objektin sijanvalinta ja sijanvalinnan taustalla oleva päättelyprosessi. Pro gradu -tutkielma. Helsingin yliopiston suomen kielen, suomalais-ugrilaisten ja pohjoismaisten kielten ja kirjallisuuksien laitos. http://urn.fi/URN:NBN:fi-fe2012112310021

Halliday, Michael 2003. On Language and Linguistics. Volume 3 in the Collected Works of M. A. K Halliday. Johnathan Webster (Ed.). London: Continuum.

Halonen, Mia 2007. Monikielinen Suomi - maahanmuuttajataustaisten koululaisten suomen kielen taidosta. - Nuorisotutkimus 25, 33-49.

Halonen, Mia 2009. Puhutun kielen variantit resurssina monikielisten koululaisten kirjoitelmissa. - Virittäjä 113 (3), 329-355.

Hopper, Paul J. 1987. Emergent grammar. - Berkeley Linguistics Society 13, 139157.

Hopper, Paul J. 1998. Emergent Grammar. - Michael Tomasello (Ed.). The New Psychology of Language: Cognitive and Functional Approaches to Language Structure. London: Lawrence Erlbaum Associates, 155-176. 
ISK = Auli Hakulinen, Maria Vilkuna, Riitta Korhonen, Vesa Koivisto, Tarja Riitta Heinonen, Irja Alho 2004. Iso suomen kielioppi. SKS:n toimituksia 950. Helsinki: Suomalaisen Kirjallisuuden Seura.

Ivaska, Ilmari, Kirsti Siitonen 2011. Avainrakenneanalyysi. Tapa tutkia oppijankielen lauserakennetta korpusvetoisesti. - Esa Lehtinen, Sirkku Aaltonen, Merja Koskela, Elina Nevasaari, Mariann Skog-Södersved (Toim.). AFinLAe Soveltavan kielitieteen tutkimuksia 3, 35-47. http://ojs.tsv.fi/index. php/afinla/article/view/4455/4252 (28.8.2014).

Ivaska, Ilmari 2011. Lausetyyppien sekoittuminen edistyneessä oppijansuomessa näkökulmana eksistentiaalilause. - Lähivõrdlusi. Lähivertailuja 21, 65-85. http://dx.doi.org/10.5128/LV21.03

Ivaska, Ilmari 2012. Keystructure analysis of formally defined structures of learner Finnish. - Esitelmä Oulun yliopiston Learner Language, Learner Corpora -konferenssissa 5.10.2012.

Kajander, Mikko 2013. Suomen eksistentiaalilause toisen kielen oppimisen polulla. Jyväskylä studies in humanities 220. Jyväskylä: Jyväskylän yliopisto. http:// urn.fi/URN:ISBN:978-951-39-5530-4

Kalliokoski, Jyrki 2008. Suomi toisena kielenä ja koulussa kirjoittaminen. - Sara Routarinne, Tuula Uusi-Hallila (Toim.). Nuoret kielikuvassa: kouluikäisten kieli 2000-luvulla. Tietolipas 220. Helsinki: Suomalaisen Kirjallisuuden Seura, 349-370.

Kielipankki 2004 = Suomen sanomalehtikielen taajuussanasto. Kielipankki, CSC Tieteen tietotekniikan keskus Oy. http://www.csc.fi/tutkimus/alat/kielitiede/taajuussanasto-B9996/view (2.5.2014).

Kittilä, Seppo 2002. Transitivity: Towards a Comprehensive Typology. Yleisen kielitieteen julkaisuja 5. Turku: Turun yliopisto.

Kokkonen, Anna-Reetta 2012. Objektin sijanvaihtelu suomenruotsalaisten ammatillisten opiskelijoiden teksteissä. Pro gradu -tutkielma. Helsingin yliopiston suomen kielen, suomalais-ugrilaisten ja pohjoismaisten kielten ja kirjallisuuksien laitos.

Kotilainen, Lari 2007. Konstruktioiden dynamiikkaa. Helsinki: Helsingin yliopiston suomen kielen ja kotimaisen kirjallisuuden laitos.

Kuusela, Jorma, Aulikki Etelälahti, Åke Hagman, Raisa Hievanen, Krister Karppinen, Leena Nissilä, Ulla Rönnberg, Marjatta Siniharju 2008. Maahanmuuttajaoppilaat ja koulutus - tutkimus oppimistuloksista, koulutusvalinnoista ja työllistymisestä. Helsinki: Opetushallitus. 
Langacker, Ronald 1987. Foundations of Cognitive Grammar. Vol. 1. Theoretical Prerequisitions. Stanford: Stanford University Press.

Larjavaara, Matti 1991. Aspektuaalisen objektin synty. - Virittäjä 95 (4), 372-408. Larjavaara, Matti 1992. Objekti ja rajattuus. - Virittäjä 96 (2-3), 272-282.

Lauranto, Yrjö 1997. Ensi askeleita paikallissijojen käyttöön. Espanjankielisten suomenoppijoiden sisä- ja ulkopaikallissijat konseptuaalisen semantiikan näkökulmasta. Kakkoskieli 2. Helsinki: Helsingin yliopisto.

Leino, Jaakko 2001a. Antamiskehys kognitiivisena konstruktiona. - Pentti Leino, Ilona Herlin, Suvi Honkanen, Lari Kotilainen, Jaakko Leino, Maija Vilkkumaa (Toim.). Roolit ja rakenteet: henkilöviitteinen allatiivi Biblian verbikonstruktioissa. SKS:n toimituksia 813. Helsinki: Suomalaisen Kirjallisuuden Seura, 67-103.

Leino, Jaakko 2001b. Antamiskehyksen laajentumat. - Pentti Leino, Ilona Herlin, Suvi Honkanen, Lari Kotilainen, Jaakko Leino, Maija Vilkkumaa (Toim.). Roolit ja rakenteet: henkilöviitteinen allatiivi Biblian verbikonstruktioissa. SKS:n toimituksia 813. Helsinki: Suomalaisen Kirjallisuuden Seura, 220257.

Leino, Jaakko 2003. Antaa sen muuttua: suomen kielen permissiivirakenne ja sen kehitys. SKS:n toimituksia 900. Helsinki: Suomalaisen Kirjallisuuden Seura.

Leino, Jaakko 2010. Adele E. Goldberg - Väitöskirjalla klassikoksi. - Pentti Haddington, Jari Sivonen (Toim.). Kielentutkimuksen modernit klassikot. Kognitiivinen ja funktionaalinen kielitiede. Helsinki: Gaudeamus, 71-98.

Leino, Pentti 1991. Lauseet ja tilanteet: suomen objektin ongelmia. Suomi 160. Helsinki: Suomalaisen Kirjallisuuden Seura.

Leino, Pentti 2001. Verbit, konstruktiot ja lausetyypit. - Pentti Leino, Ilona Herlin, Suvi Honkanen, Lari Kotilainen, Jaakko Leino, Maija Vilkkumaa (Toim.). Roolit ja rakenteet: henkilöviitteinen allatiivi Biblian verbikonstruktioissa. SKS:n toimituksia 813. Helsinki: Suomalaisen Kirjallisuuden Seura, 11-66.

Leino, Pentti, Ilona Herlin, Suvi Honkanen, Lari Kotilainen, Jaakko Leino, Maija Vilkkumaa (Toim.) 2001. Roolit ja rakenteet: henkilöviitteinen allatiivi Biblian verbikonstruktioissa. SKS:n toimituksia 813. Helsinki: Suomalaisen Kirjallisuuden Seura.

Lesonen, Sirkku 2013. Suomen kielen lingvististen piirteiden sijoittuminen eurooppalaisen viitekehyksen taitotasoille. Pro gradu -tutkielma. Jyväs- 
kylän yliopiston kielten laitos, suomen kieli. http://urn.fi/URN:NBN:fi: jyu-201302241264

Löflund, Juhani 2001. Suomen objektin oppimisen ja opettamisen vaikeuksia. Eeva Lähdemäki, Pia-Maria Kallio, Michaela Pörn (Toim.). Kiinnostuksesta kieleen. Åbo Akademin Fennistica 13. Åbo, 94-126.

Lynch, Tony, Joan Maclean 2000. Exploring the benefits of task repetition and recycling for classroom language learning. - Language Teaching Research 4 (3), 221-250. http://dx.doi.org/10.1177/136216880000400303

MacWhinney, Brian 2000. The CHILDES Project: Tools for analyzing talk. 3rd edition. Vol. 2: The Database. Mahwah, NJ: Lawrence Erlbaum Associates.

Martin, Maisa, Sanna Mustonen, Nina Reiman, Marja Seilonen 2010. On becoming an independent user. - Inge Baartning, Maisa Martin, Ineke Vedder (Eds.). Communicative Proficiency and Linguistic Development: Intersections between SLA and Language Testing Research. Eurosla Monographs Series 1. European Second Language Association, 57-81.

Martin, Maisa 2013. Sentences and clauses as complexity measures in second language writing: A segmentation experiment. - Marja Järventausta, Marko Pantermöller (Toim.). Finnische Sprache, Literatur und Kultur im deutschsprachigen Raum - Suomen kieli, kirjallisuus ja kulttuuri saksankielisellä alueella. Veröffentlichungen der Societas Uralo-Altaica 85. Wiesbaden: Harrassowitz, 185-198.

Mäntynen, Anne 2006. Näkökulmia tekstin ja tekstilajien rakenteeseen. - Anne Mäntynen, Susanna Shore, Anna Solin (Toim.). Genre - tekstilaji. Tietolipas 213. Helsinki: Suomalaisen Kirjallisuuden Seura, 42-71.

Määttä, Tuija 2011. Ruotsinkielisten alkeistason suomenoppijoiden paikallissijojen käytöstä. - Lähivõrdlusi. Lähivertailuja 21, 154-184. http://dx.doi. org/10.5128/LV21.07

Newport, Elissa L. 2014. Statistical language learning: Computational, maturational, and linguistic constraints. - Plenary talk on the GURT 2014 (Usagebased Approaches to Language, Language Learning, and Multilingualism) conference at Georgetown University, Washington DC 14.3.2014.

Reiman, Nina, Sanna Mustonen 2010. Yläkoulun suomi toisena kielenä -oppilaiden kirjoittamistaito. - Kasvatus 2, 143-153.

Reiman, Nina 2011. Transitiivikonstruktio ikkunana syntaksin kehitykseen: infiniittiset rakenteet ja passiivi taidon indikaattoreina S2-oppijoiden teksteissä. - Esa Lehtinen, Sirkku Aaltonen, Merja Koskela, Elina Nevasaari, Mariann Skog-Södersved (Toim.). AFinLAe Soveltavan kieli- 
tieteen tutkimuksia 3, 142-157. http://ojs.tsv.fi/index.php/afinla/article/ view/4465/4259 (28.8.2014).

Salmi, Niina 2010. Virkkeiden ja lauseiden piirteitä edistyneiden suomenoppijoiden teksteissä. Pro gradu -tutkielma. Turun yliopisto. http://urn.fi/ URN:NBN:fi-fe201301221635

Seilonen, Marja 2013. Epäsuora henkilöön viittaaminen oppijansuomessa. Jyväskylä Studies in Humanities 197. Jyväskylä: Jyväskylän yliopisto. http://urn. fi/URN:ISBN:978-951-39-5025-5

Seppälä, Tanja 2013. Oppijansuomen kolligaatit ketjuuntuvissa verbirakenteissa. Lähivõrdlusi. Lähivertailuja 23, 315-340. http://dx.doi.org/10.5128/ $\underline{\text { LV23.13 }}$

Siivelt, Keaty, Sanna Mustonen 2013. Lähdekielen vaikutus ja kielitaitotasot: paikallissijojen kehitys oppijansuomessa. - Lähivõrdlusi. Lähivertailuja 23, 341-370. http://dx.doi.org/10.5128/LV23.14

Spoelman, Marianne 2012. Prior linguistic knowledge matters: The use of the partitive case in Finnish learner language. Acta Universitatis Ouluensis Humaniora 111. Oulu: University of Oulu. http://urn.fi/ urn:isbn:9789526201146

Suni, Minna 2008. Toista kieltä vuorovaikutuksessa. Kielellisten resurssien jakaminen toisen kielen omaksumisen alkuvaiheessa. Jyväskylä Studies in humnanities 94. Jyväskylä: Jyväskylän yliopisto. http://urn.fi/ URN:ISBN:978-951-39-3209-1

Tarnanen, Mirja, Katja Mäntylä 2006. Toisen ja vieraan kielen oppijat yleisissä kielitutkinnoissa. - Päivi Pietilä, Pekka Lintunen, Heini-Marja Järvinen (Toim.). Kielenoppija tänään - Language Learners of Today. AFinLA:n vuosikirja 2006. Suomen soveltavan kielitieteen yhdistyksen julkaisuja 64 . Jyväskylä, 105-123.

Theakston, Anna L., Robert Maslen, Elena V. M. Lieven, Michael Tomasello 2013. The acquisition of the active transitive construction in English: A detailed case study. - Laura A. Janda (Ed.). Cognitive Linguistics: The Quantitative Turn. Berlin: Walter de Gruyter, 103-140.

Tomasello, Michael 1992. First Verbs: A Case Study of Early Grammatical Development. Cambridge: Cambridge University Press. http://dx.doi.org/10.1017/ CBO9780511527678

Tomasello, Michael 2003. Constructing a Language: A Usage-Based Theory of Language Acquisition. Harvard: Harvard University Press.

Tyler, Andrea 2012. Cognitive Linguistics and Second Language Learning: Theoretical Basics and Experimental Evidence. New York: Routledge. 
Verhagen, Arie 2005. Constructions of Intersubjectivity: Discourse, Syntax, and Cognition. Oxford, New York: Oxford University Press.

Västi, Katja 2012. Verbittömät tapahtumanilmaukset. Suunnannäyttäjinä lähdeja kohde-konstruktio. Acta Universitatis Ouluensis. Series B, Humaniora vol. 107. http://urn.fi/urn:isbn:9789526200248

\section{Nina Reiman}

PL 35 (Mattilanniemi/Kärki)

40014 Jyväskylän yliopisto, Finland

nina.reiman@jyu.fi 


\title{
Lower secondary school L2 Finnish students' use of transitive expressions at the CEFR levels
}

\author{
NINA REIMAN \\ University of Jyväskylä
}

This study concentrates on the development of transitive expressions in texts written by lower secondary school learners of Finnish as a second language. The specific aim is to analyze how the young writers use a common and versatile type of syntactic pattern, the transitive construction, in learner Finnish, and to clarify how its different instantiations change and vary as language proficiency develops. The research data consists of texts written by L2 students from grades 7-9. These writings have been collected in the Cefling-project at the University of Jyväskylä and they have been rated on a functional CEFR scale at levels A1-C2. The texts are analyzed based on the frequency and accuracy of transitive expressions. The qualitative analysis is grounded in a usage-based and Construction Grammarian approach to language, and more specifically in the argumentative environments in which learners use the transitive expressions.

The results indicate that the transitive construction is used fairly evenly at the different proficiency levels. However, the number of instantiations varies according to task: whereas informal messages contain fewer expressions, argumentative texts and formal messages display a clearly higher number. The accuracy of the expressions increases steadily from one proficiency level to the next, and $80 \%$ accuracy is achieved at level B1. At level A1 the argument structure of the expressions is still quite simple. Nonetheless, at this level learners already attempt to use e.g. the caused motion construction and the ditransitive (Finnish TO GIVE) construction. From level A2 onwards instantiations of the argument structure constructions increase while their use starts to vary and becomes more accurate. The use of the transitive construction begins to extend beyond prototypical cases.

Keywords: second language acquisition; learner language; construction grammar; syntax; transitivity; Finnish 